\title{
Status of Hydrogen Fuel Cell Electric Buses Worldwide
}

\author{
Thanh Hua* and Rajesh Ahluwalia \\ Argonne National Laboratory, Argonne, Illinois \\ Leslie Eudy \\ National Renewable Energy Laboratory, Golden, Colorado \\ Gregg Singer \\ BC Transit, British Columbia, Canada \\ Boris Jermer \\ HyCologne, Germany \\ Nick Asselin-Miller \\ Element Energy, Cambridge, United Kingdom \\ Silvia Wessel \\ Ballard, Burnaby, BC, Canada \\ Timothy Patterson \\ ClearEdge Power, Hartford, Connecticut
}

June 2014

*Corresponding author: Thanh Hua

Argonne National Laboratory, 9700 South Cass Avenue, Argonne, IL 60439

Email: hua@anl.gov

Telephone: (630) 252-7753

(C) 2014. This manuscript version is made available under the Elsevier user license 


\begin{abstract}
This review summarizes the background and recent status of the fuel cell electric bus (FCEB) demonstration projects in North America and Europe. Key performance metrics include accumulated miles, availability, fuel economy, fuel cost, roadcalls, and hydrogen fueling. The state-of-the-art technology used in today's fuel cell bus is highlighted. Existing hydrogen infrastructure for refueling is described. The article also presents the challenges encountered in these projects, the experiences learned, as well as current and future performance targets.
\end{abstract}

Key words: Fuel cell electric bus, fuel cell technology, hydrogen refueling, hydrogen infrastructure, public transportation.

\title{
1. Introduction
}

For years, developed countries have made great strides toward improving air quality in densely populated metropolitan cities and advocated the need to use alternative energy sources to petroleum as the pathway toward reducing transportation-related air pollution. Heavy-duty vehicles, especially electric busses powered by hydrogen fuel cells will be an important element in any plan to achieve the targets for air quality and pollution reduction.

There are numerous operational, environmental and economic benefits of fuel cell electric buses (FCEBs) over traditional diesel or diesel hybrid busses. FCEBs are more fuel efficient [1] as shown in Figure 1. These buses operate with no local emissions, reduced noise, and a substantial reduction in greenhouse gas emissions on a well-to-wheel basis without some of the performance, range and route flexibility issues seen in other zero emission technologies [2]. Use of fuel cells for transit reduces dependence on petroleum and adverse effects of price fluctuations. For these reasons, FCEBs are progressing towards commercialization and the number of FC bus and FC manufacturers are increasing steadily (Figure 2). With about 100 buses on the road in demonstration projects across the globe, FCEBs are approaching government and transit agency targets in technical performance, durability and reliability. There remain, however, a few barriers to reaching full commercialization of FCEBs. The major barriers include durability of the fuel cell power systems, the relatively high initial capital cost of fuel cell buses, and the availability and cost of hydrogen. These barriers will be overcome with continuing improvement in fuel cell technology, high volume manufacturing, and establishment of large refueling facilities (1000 $\mathrm{kg}$ /day). Table 1 [3] summarizes current active FCEBs in the world. The majority of them are located in North America and Europe. Collectively, they have accumulated over 3 million miles of successful operation.

In the United States, the Federal Transit Administration established the national Fuel Cell Bus program in 2006 to advance the commercialization of FCEBs. The program has provided nearly $\$ 90$ million since 2006 to promote the development and testing of cleaner, greener sources of fuel for the transit industry. As of August 2013, there are 18 active FCEBs in demonstrations at 
six locations [4]. Fourteen of the 18 busses are in the state of California. This review summarizes data collected for the data period from August 2012 to July 2013 from five different FCEB demonstrations at four transit agencies. These include 12 Van Hool buses with ClearEdge

Power (formerly UTC Power) fuel cells (ZEBA) at AC Transit, Oakland, CA; 4 Van Hool buses with ClearEdge Power fuel cells (Nutmeg) at CTTRANSIT, Hartford, CT; 1 New Flyer bus with Ballard fuel cell and 1 Eldorado bus with Ballard fuel cell at SunLine, Thousand Palms, CA; and 1 Proterra bus with Hydrogenics fuel cell at Capital Metro, TX.

In Europe, the HyFLEET-CUTE demonstration project with 30 full size Daimler buses in 10 cities accumulated 1.3 million miles between 2003-2010 [5]. These buses were battery dominant with $12 \mathrm{~kW}$ Hydrogenics fuel cells. Building on the HyFLEET-CUTE success, the European fuel cell bus CHIC (Clean Hydrogen in European Cities [6]) demonstration projects currently has 26 FCEBs in Phase 1 operating in 5 countries: 5 Daimler buses with AFCC fuel cells in Switzerland, 5 Van Hool buses with Ballard fuel cells in Norway, 8 Wrightbus buses with Ballard fuel cells in the United Kingdom, and 8 Daimler busses with AFCC fuel cells in Italy. This fleet will run from 2011 to 2017 with the aim to achieve a number of performance targets which will ease the integration of the technology into today's public transport standards. The CHIC projects are supported and funded by the Joint Technology Inititatives' (JTI) Fuel Cell and Hydrogen Joint Undertaking (FCH-JU) and a set of industry partners.

Additionally, the High V.LO City project [7] in Europe is deploying 14 FCEBs (all Van Hool busses) in 3 countries: Italy, Scotland and Belgium. HyTransit is another program sanctioned by EU, under which Van Hool and Ballard will supply 6 fuel cell buses to City of Aberdeen, Scotland, similar in design to High V.LO City buses. These projects aim to create a network of successful fuel cell bus operation sites, so called Clean Hydrogen Bus Centres of Excellence (CHBCE), linking High V.LO-City sites with similar fuel cell bus demonstrations in Europe. Both the High V.LO City and HyTransit projects are supported through the EU's JTI program.

In Canada, BC Transit has operated a fleet of 20 New Flyer buses with Ballard fuel cells that were deployed in time for the 2010 Winter Olympics. This fleet operates as the backbone of the transit service in the Resort Municipality of Whistler and has surpassed 1.9 million revenue miles [8]. It continues to be the largest fuel cell fleet to operate in a single location at one time. It also requires the largest hydrogen fueling station in the world to provide the fuel for the fleet with a dispensing capacity of $1,000 \mathrm{~kg} /$ day. The hydrogen is shipped and stored in liquid form and dispensed into the demonstration fleet in a gaseous state.

In Japan, HINO (Toyota's bus subsidiary and the only fuel cell bus player) is operating 6 FCEBs with 90-kW Toyota fuel cells in various locations [9]. These buses were first deployed in 2005 as shuttles at the Aichi Expo. Although Toyota is one of the automakers most committed to light duty fuel cell vehicles, interest in the bus market is unclear. 
In Korea, the situation is similar to Japan. Huyndai is the key fuel cell/OEM player. Huyndai is committed to commercial light duty fuel cell vehicles by 2014 , but plans for buses are unclear. A Hyudai 40-ft bus with Hyundai $160 \mathrm{~kW}$ fuel cell has operated since 2006 in routine service in Seoul and Jeju island. Hyundai has a contract with Seoul to start supplying multiple FCEBs starting in 2013 [10].

In China, since 2005 FCEBs have been deployed for major events with global spotlight including 3 buses for the 2008 Summer Olympics and 6 for the 2010 Shanghai Expo [11]. In November and December 2010 a fleet of more than 50 fuel cell buses shuttled athletes and government officials to various venues of the Asian Games in Guangzhou City. These demo buses are no longer in service. In September 2013, Ballard announced a multi-year agreement to support Azure Hydrogen's fuel cell bus program for the Chinese market [12].

In Brazil and India, dozens of FCEBs with Ballard fuel cell are being planned for deployment within next few years $[13,14]$.

This review article summarizes the performance data of FCEBs deployment globally, the status of fuel cell technology being used in FCEBs, the current hydrogen fueling infrastructure, and concludes with projections and targets for the next generation of FCEBs.

\section{Fuel Cell Bus Activities in the United States}

A timeline of FCEB development in the United States is shown in Figure 3. In 2006, the Federal Transit Administration (FTA) established the National Fuel Cell Bus Program (NFCBP) to advance the research and demonstrations of FCEBs. This multi-year, cost-shared program has provided more than $\$ 180$ million (including 50\% cost share) for various research projects, FCEB demonstrations, component development projects and outreach projects. The projects are managed through three nonprofit consortia - CALSTART (Pasedena, California), the Center for Transportation and the Environment (CTE, Atlanta), and the Northeast Advanced Vehicle Consortium (NAVC, Boston). The National Renewable Energy Laboratory (NREL) was funded as a third-party evaluator to assess the viability of the buses demonstrated under the program.

In addition to the projects currently underway and listed in Table 1, seven more FCEBs will be deployed over the next year. Beyond the NFCBP, FTA funds fuel cell bus research at several universities and transit agencies. Details were documented in a recent FTA report [15].

\subsection{Performance Data}

The data presented in this section were compiled by the National Renewable Energy Laboratory (NREL) and represent the most recent published results through July 2013 [4]. These data come from five different FCEB demonstrations at four agencies: AC Transit, CTTRANSIT, SunLine, and Capital Metro. All but one of the FCEBs presented in this section have hybrid systems that 
are fuel cell dominant. The Proterra bus is a battery dominant system. Table 2 provides some specifications of the FCEBs. The FCEBs are pictured in Figure 4.

Conventional baseline bus data are provided for all three agencies for comparison with FCEB data. For AC Transit and CTTRANSIT, the primary comparisons are with diesel buses. The baseline buses at SunLine are CNG because the agency doesn't operate diesel buses.

\section{Total miles and hours}

Table 3 summarizes miles, hours, average speed, and average monthly miles per bus for the FCEBs. The AFCB at SunLine has the highest average speed at $15.3 \mathrm{mph}$, followed by the Nutmeg buses at $12.8 \mathrm{mph}$. SunLine AT bus operates primarily on one specific route, while the AFCB has operated on several routes within the service area. The ZEBA buses in service at AC Transit have the lowest average speed at just under $9 \mathrm{mph}$. The transit agencies continue to operate their fuel cell buses fewer miles than they operate their baseline buses; however there is a general upward trend for the fuel cell buses. Figure 5 shows the average monthly bus use for the fuel cell buses and their respective baseline buses. Some buses have operated as much as 20 hours in a day, 7 days per week.

\section{Availability}

Availability is the percentage of days that buses are planned for operation compared to the percentage of days the buses are actually available. Table 4 summarizes the availability of the fuel cell buses at each transit agency. Availability varies from site to site with a low of $31 \%$ and a high of $81 \%$. The average availability for the group is $69 \%$. Figure 6 tracks the monthly availability for the FCEBs by project. The percent availability is shown as a separate line for each of the projects with the combined overall average for all FCEBs in dark blue.

The availability of the SL AFCB (shown as a dark green line in the graph) has been quite good, at or over the $85 \%$ target for 7 of the 12 months in service. In March 2013, the bus developed a coolant leak that proved difficult to locate. This problem, eventually traced to the radiator, caused the availability to drop during the end of the data period.

The ACT ZEBA (medium blue line in the graph) buses were out of service during the beginning of the data period while the hydrogen station was down. Once the buses went into service, the availability showed an increase over its past availability data. The buses at CTTRANSIT (light blue line) are the same design as the ZEBA buses. The availability during the period began low but increased over time. One of the four buses was moved to Flint, Michigan, and has been in service there for the entire data period. When the planned demonstration ended in early 2013, ClearEdge Power ended service for the three remaining buses at CTTRANSIT. ClearEdge has made a business decision to focus on the stationary power market and will transfer the ownership of the buses to other parties. 
The Proterra bus in Texas had several issues during its planned demonstration that caused extended downtime. The primary issues have been with the hybrid propulsion system and the fuel cell. The bus availability for December calculates to $100 \%$; however it was only scheduled for eight days during the month.

Figure 7 presents the overall monthly availability and shows the reasons that the buses were not available by category. The blue line on the graph is the combined monthly availability for the buses in all five demonstration projects. The stacked bars show the total number of days the buses were unavailable each month by primary system category. The majority of issues affecting the availability for the buses were general maintenance $(52 \%)$, followed by traction batteries (21\%), fuel cell system (20\%), and hybrid system (7\%).

\section{Fuel economy}

Figure 8 shows the average fuel economy in miles per diesel gallon equivalent (DGE) for each type of FCEB compared to the conventional baseline bus technology at the same site. The fuel economy for hybrid fuel cell systems tends to vary from site to site depending on the duty-cycle. The FCEBs continued to show improved fuel economy compared to the baseline buses in similar service. New FC bus designs have twice the fuel economy as diesel buses. FTA's performance target for FCEB fuel economy is at least two times higher than that of diesel buses. The FCEBs showed improved fuel economy ranging from 1.8 to 2.4 times higher than the fuel economy of diesel and CNG baseline buses.

\section{Roadcalls}

A roadcall or revenue vehicle system failure is a failure of an in-service bus that causes the bus to be replaced on route or causes a significant delay in schedule. If the bus is repaired during a layover and the schedule is maintained, then no roadcall is recorded. Figure 9 shows miles between roadcalls (MBRC) for all roadcalls, for propulsion-related-only roadcalls, and for fuelcell-system-only roadcalls for the FCEBs during the data period. The gray dotted line marks the target for all MBRC $(4,000)$ and the brown and red hashed lines are the 2016 and ultimate targets for FC system (15,000 and 20,000 miles, respectively). Most recent data indicate that FC MBRC has increased to 17,558 miles, exceeding the 2016 target. While the bus MBRC rates are still lower than the targets, the reasons are not typically due to the fuel cells.

\section{Hydrogen fueling}

NREL has tracked total hydrogen use for FCEBs at all of the sites. Since the first bus went into service in January 2006 through July 2013, these FCEBs have been fueled with more than $150,000 \mathrm{~kg}$ of hydrogen with no fueling safety incidents. The amount of hydrogen dispensed continues to grow as new buses are placed into service. Figure 10 shows the total hydrogen dispensed for the three primary sites. During the data period from August 2012 through July 
2013, the FCEBs at the three sites were fueled 1,835 times with a total of 35,754 kg of hydrogen. The average fill amount for these fuel cell dominant FCEBs was about $19.5 \mathrm{~kg}$ per fill.

\subsection{Achievements and Challenges}

While bus performance and fuel cell system durability have continued to improve, there are still major challenges to overcome to move FCEB technology to a commercial product. This section outlines the on-going challenges as well as lessons learned from recent issues.

\section{Integration/optimization of components}

Over the past years, manufacturers continued to work on issues with systems integration and optimization, which is still one of the major challenges for FCEBs. When new FCEB designs first go into service, there is a characteristic break-in period where the manufacturers review the early performance results and make changes to optimize and correct any issues that occur. This break-in period can take many months as new issues arise that did not show up in laboratory testing. In many cases, the issue is due to communication problems between the different subsystems that can be resolved through software updates.

\section{Hydrogen fueling}

Access to hydrogen fuel continues to be one of the biggest hurdles to adoption of any fuel cell vehicle. Several demonstration projects have been delayed because of issues with access to fuel. There is a need to develop large stations at transit agencies that could handle larger fleets of buses. One of those stations began operation in August 2011 at AC Transit's Emeryville Division [1]. The Emeryville station is a combined facility for light-duty fuel cell electric vehicles and FCEBs. Hydrogen is provided from two sources: liquid hydrogen delivery and a solar-powered electrolyzer. The electrolyzer is capable of producing $65 \mathrm{~kg}$ of hydrogen per day. When combined with the delivered liquid hydrogen, the station has the capacity to dispense up to $600 \mathrm{~kg}$ of hydrogen per day.

\section{FCEB development teams}

Developing a new propulsion system for buses takes a cohesive team of manufacturers working closely to identify and solve some potentially complex problems. Transit bus orders in the United States are typically produced by the bus manufacturer. The bus original equipment manufacturer (OEM) orders the specified components—such as engine, transmission, and seats-which are installed at the factory. When the first hybrid-electric propulsion systems were designed, the hybrid system manufacturer took the lead in the installation and testing of the first diesel-hybrid buses. Once the system was optimized and ready for commercial production, the hybrid system manufacturer worked with the bus OEM to train them to install the system at the 
factory. At that time, the propulsion system became another standard system installed in the bus just like any other sub-system. This is the eventual goal for a fuel-cell-hybrid system.

The development teams for FCEBs are facing challenges similar to those of the hybrid bus developers, but with the added difficulty of optimizing communication and interfaces between advanced systems. The hybrid system, fuel cell, and batteries must all work together to propel the bus. These systems are produced by different companies, each with its own concerns over intellectual property. Overcoming issues of sharing sensitive data is a challenge within the teams. In the current economic climate, many manufacturers have had difficulties remaining engaged in the process. In some instances, a partner drops out of the team because of resource constraints. In some cases, a company declares bankruptcy. These unforeseen problems are difficult to overcome if other partners can't step up their level of support. These types of issues have caused delays in getting buses ready for service but have also contributed to extended downtime for the buses.

\subsection{Summary}

Highlights of progress with $2^{\text {nd }}$ generation FCEBs in the United States include

- Mileage accumulation at 2000 miles/month

- FCEB fuel economy consistently higher than diesel and CNG baseline buses

- FCEB designs approach twice the fuel economy of diesel and CNG baseline, meeting target of 8 mpdge

- Average availability at $69 \%$ with most recent availability at up to $100 \%$

- Fuel cell system MBRC is increasing $-56 \%$ improvement over $1^{\text {st }}$ generation FCEBs

- Reliability data show road calls not typically due to FC system

- Top FC power plant surpasses 12,000 hours

\section{Fuel Cell Bus Activities in Europe}

The European Union (EU) is committed to significantly reducing its greenhouse gas (GHG) emissions and in order to meet their target of an 80 percent reduction from 1990 levels, road transport emissions may need to be cut by as much as 95 percent [16]. As a result, and in parallel with increasingly stringent vehicle emissions regulations, a range of alternative drivetrain technologies are being rolled out and supported through both European and national funding schemes.

The current level of technical readiness for FCEBs is seen as significantly better than equivalent battery electric buses (e.g., opportunity or overnight e-buses), with over 30 standard 12-m or 18$\mathrm{m}$ hydrogen fuel cell buses deployed across Europe, but no equivalent electric buses in operation, as shown in Figure 11. 
Many of the existing FCEB deployments have been supported by the European Fuel Cell and Hydrogen Joint Undertaking (FCH JU), a public-private partnership between the EU and Industry, with the aim of supporting the commercialization of hydrogen and fuel cell-based technologies in Europe.

The first major coordinated FCEB deployments in Europe occurred through the CUTE and HyFleet:CUTE projects, which ran from 2003-2009 and deployed a total of 27 non-hybridized FCEBs in 9 European cities. This was followed by the CHIC project which began in 2011 with the aim of deploying 26 new hybridized FCEBs across five European cities from 2012 onwards, while also sharing lessons learned and data with existing FCEB deployments in three other European cities. This has been followed by the HyTransit and High.V.Lo.City, which will deploy 6 of the latest generation of hybridized FCEBs in Aberdeen and 14 FCEBs in three European regions respectively. Table 5 lists the cities/regions with active FCEB fleets in Europe.

Additionally, a number of European and global cities and regions (including Amsterdam, Barcelona, Berlin, British Columbia, Cologne, Hamburg, London, South Tyrol and Western Australia) with large bus fleets have formed the Hydrogen Bus Alliance (HBA), with the aim of sharing information on the performance of and lessons learned from deployed FCEBs, as well as collaborating on future potential FCEB procurements. These cities and regions represent a cumulative fleet of over 12,000 buses and an average purchase of over 1,200 city buses each year. They are characterized by high level political support for hydrogen bus deployment programs and all intend to move towards procuring hydrogen buses on a continuous basis as hydrogen buses move towards commercial viability.

The latest round of FCEBs deployed are based on series hybrid technology, with a choice of either batteries or super capacitors (depending on the journey profile) storing power from regenerative braking and providing a buffer to allow minimal sizing of the fuel cell system, thereby minimizing costs.

In parallel with these bus deployments, each of the above cities has also deployed hydrogen refueling infrastructure to service the bus fleets. These have ranged from solutions relying on liquid hydrogen deliveries to refill local storage tanks, to on-site electrolysis for green hydrogen production.

\subsection{Performance data}

Although the HyFleet:CUTE project reported on reliability and performance data for nonhybridized FCEBs over the period 2003-2009 (>92\% bus availability, $>2$ million km driven, $<10$ road calls per $1,000 \mathrm{~h}$ operation [17]), there is currently limited publically available data from the follow-on CHIC project and its new generation of hybridized FCEBs. 
Early indications from CHIC are that there has been a step change improvement in performance from the earlier non-hybridized generation of FCEBs and that current environmental and fuel cell reliability performance has been either in-line with or slightly better than the performance of United States and Canadian FCEB fleets. However teething problems with many of the bus fleets' non-fuel cell components has led to availabilities being below expected targets, at least in the early part of deployments. A number of easily avoidable issues have been singled out as unnecessarily causing a reduction in availability:

- Supply chain issues: Extended downtime due to unavailability of, or long lead times on spare parts.

- Software teething problems: Initial low availability of vehicles in service was often due to 'false' error signals, over sensitive error messages, or other problems caused by differences between testing in an artificial scenario and in true passenger service.

- Poorly prepared support staff and local employees: Transit agencies had patchy safety knowledge with regards to hydrogen, tank inspection, pressure systems, thereby causing extended downtime as a result of minor faults.

Despite the current lack of official data from the CHIC project, some initial data from the hybridized FCEBs deployed in London has been released by Transport for London, as described below.

\section{Fuel Consumption}

Fuel consumption for the fleet of hybridized FCEBs in London has been on average around 9 $\mathrm{kg} / 100 \mathrm{~km}$, which is significantly below the $11-13 \mathrm{~kg} / 100 \mathrm{~km}$ target set by the FCH JU and less than half of the $22 \mathrm{~kg} / 100 \mathrm{~km}$ observed from the non-hybridized FCEBs in the CUTE and HyFleet:CUTE projects, as shown in Figure 12 .

The fuel consumption observed is also an improvement over the calorific equivalent consumption of a diesel bus (equivalent consumption of $11-15 \mathrm{~kg} / 100 \mathrm{~km}$ ).

\section{Availability}

Availability for the fleet of FCEBs deployed in London has been significantly below that for equivalent diesel buses, as shown in Figure 13. This is also below the $92 \%$ availability observed for the non-hybridized FCEBS in the CUTE and HyFleet:CUTE projects. 
However, as illustrated in Figure 13, there is a clear upward trend in availabilities due to the fact that many of the issues observed towards the start of the deployment were related to early teething problems and supply chain issues, as previously described. The trend is towards an improved overall availability level above $70 \%$ for all the buses deployed.

On an individual bus basis however, availabilities of over $90 \%$ have been achieved as shown in Figure 14. This illustrates that the technology is capable of very high levels of availability similar to that observed with diesel buses, although this is not being achieved on a consistent basis due to an immature supply chain and some component specific problems.

Figure 15 illustrates that much of the downtime observed with the London FCEB deployment has been unrelated to the fuel cell systems, but rather has been attributable to balance of plant issues, as well as unexplained warning lights (22\% of downtime under 'OTHER (h2/hybrid related)'). It is expected that these types of issue will gradually be resolved as the current generation of FCEBs settles into service across the CHIC project and as the next generation of FCEBs are deployed in future projects, allowing the buses to achieve much closer to their potential availability exceeding $90 \%$.

The indication across the rest of the CHIC project is that with many of the early teething problems and supply chain issues being addressed, FCEB availability will show a significant improvement in the next few months of operation. However it is not expected that the current generation of hybridized FCEBs will reach the long-term availability exceeding $90 \%$ which is expected for the next generation of buses.

\section{Refueling time}

Refueling time of the FCEBs deployed in London has ranged on average between 7-10 minutes for a full refueling of $30 \mathrm{~kg}$. Note that due to the better-than-expected fuel efficiency of the FCEBs in the London fleet deployment, the onboard storage capacity was reduced from $46 \mathrm{~kg}$ to $30 \mathrm{~kg}$ by removing 2 of the 6 original storage tanks, in order to increase their passenger carrying capacity and this has had a positive effect on refueling times.

\section{Future data availability from CHIC and other European projects}

In addition to the above data, it is expected that considerably more performance and reliability data will become available over the coming year, for both European FCEB deployments from a range of projects including CHIC, and their supporting infrastructure.

\section{Fuel Cell Bus Activities in Canada}


In Canada, the British Columbia (BC) Transit was charged with implementing a demonstration project by acquiring 20 fuel cell buses to provide zero emission transit service at the Resort Municipality of Whistler (the RMOW) in time for the 2010 Winter Olympics. This fleet operates as the backbone of the transit service in the RMOW. It continues to be the largest fuel cell fleet to operate in a single location at one time. Unlike other fuel cell bus programs (where small fleets have been introduced into larger fleets), the service in the RMOW relies almost exclusively on the hydrogen fuel cell powered buses for transit service. To date, the fuel cell fleet has logged approximately 3.8 million kilometers [18].

Not only does the operation in the RMOW have the largest fuel cell bus fleet, it also requires the largest hydrogen fuelling station in the world to provide the fuel for the fleet. The hydrogen is shipped and stored in liquid form and dispensed into the demonstration fleet in a gaseous state.

The transit service in the RMOW is the most aggressive environment and duty cycle of all of BC Transit's transit systems. Coupling this environment with the largest fuel cell bus fleet and the largest hydrogen fuelling station has provided a bench test that mimics the most aggressive transit environments in Canada.

\subsection{Performance Data}

Table 6 summarizes the key performance data collected from January 2011 through May 2012. The data is shown and highlighted by the four project periods of operation. Periods 1 and 2 run from January 2010 to March 2011. During these periods, all buses were delivered to the RMOW in time for the Olympics. The buses were supported through an extensive team from Ballard, New Flyer and ISE Corp. These periods included significant commissioning and upgrades work. The fuel cell bus fleet was supplemented with a significant contingency fleet during this period to ensure that service was maintained. During Periods 1 and 2, operations and maintenance activities were generally developmental with inconsistent tracking and data recording. Data from these periods are therefore considered information only and are not used in any performance analysis.

Periods 3 and 4 run from April 2011 to May 2012. The buses were phased in through 15 day trials where each bus had to achieve 15 days of fault-free service. All buses completed the 15 day trial. Period 3 was a transitional period and is included in the analysis so that a full year can be reviewed (and to avoid seasonal skewing). Period 3 assessments result in a variety of measures that are not significantly different than Period 4. Period 4 is considered the key period for evaluation, as it reflects the closest to normal operations and is best suited to project the operational performance of the fleet for the remainder of the program.

\section{Total kilometers and hours}

Figure 16 shows the monthly and total cumulative kilometers for the whole fleet. The figure shows the increase in usage experienced in Periods 3 and 4. Early commissioning and reliability 
issues kept the fleet from being fully utilized in Periods 1 and 2. Based on 2.1 million accumulated kilometers, the fuel cell fleet has avoided 3,202 tons of $\mathrm{CO}_{2}$ emissions.

\section{Availability}

Availability was calculated using the "Whistler Allocation Sheets," which provide a daily history of the buses - deployed, under maintenance or failed in service. The data are based on morning roll out availability and shown in Figure 17. The average availability for Periods 3 and 4 was $71 \%$, but shows evidence of seasonal fluctuations. The higher availability rate for Periods 1 and 2 was the result of a large vendor presence onsite. In Periods 3 and 4, the service became more dependent on the fuel cell fleet with the removal of eight Nova diesel buses from the RMOW fleet due to service cuts.

\section{Roadcalls}

The mean distance between roadcalls (MDBRC), shown in Figure 18, was measured using Whistler Transit's maintenance records. These records yielded a fleet average MDBRC of 2,740 $\mathrm{km}$ for periods 3 and 4 but, as with availability, there is evidence of seasonal influences on fleet reliability.

\section{Fuel economy and cost}

Figure 19 shows the average monthly fuel economy of the fleet. Fuel economy decreases as the ambient temperature decreases through the winter months because the buses consume more fuel to provide heat to the passengers (via a $20 \mathrm{~kW}$ heater) and there is a sharp increase in passenger loads through the winter ski season.

Fuel cost per kilometer, shown in Figure 20, was calculated based on the monthly minimum fuel costs plus the Monthly Facility Fee (MFF) paid to Air Liquide. The cost per kilometer has been decreasing as usage of the fleet increases, due to the 'take-or-pay' terms of the contract with Air Liquide. The average cost for Periods 3 and 4 was $\$ 2.28 / \mathrm{km}$ (trending to $\$ 2.00$ with full utilization of the 'take or pay'), compared to $\$ 0.60 / \mathrm{km}$ for the Whistler 2008 Nova diesel fleet operation in 2009.

\section{Hydrogen fueling}

Figure 21 shows the quantity of fuel delivered to the site by Air Liquide. It also shows the division between fuel dispensed and fuel lost in the process. The large proportion of losses (40$45 \%$ ) is not well understood and is pending an investigation by Air Liquide and BC Transit. Usage is defined by what is dispensed at the nozzle (blue lines); therefore, the losses do not impact the program. 
Figure 22 shows the average monthly fuelling rate from the Air Liquide station. The data show a near-constant fuelling rate throughout the project and are independent of the reliability of the fleet. The target fuelling rate, established early in the project, is $5 \mathrm{~kg} /$ minute (10 minute fill for $50 \mathrm{~kg}$ ). The significantly slower fuelling rate has resulted in the requirement for an additional service person position at Whistler Transit.

\subsection{Achievements and Challenges}

The buses have achieved the contractual performance requirements, except in the following areas: availability, reliability, noise and operating range. Based on the latest operating data, without significant design changes to the demonstration fleet there will be little or no change to availability or reliability.

The operational costs for the fuel cell buses are much higher than the costs for the Nova diesel bus fleet. The fuel cell buses lag incumbent diesel technology in the following areas: fuel costs (approximately twice that of a diesel bus), bus maintenance costs (approximately twice that of a diesel bus) and fuelling service time requirements.

The fuel cell buses are capable of meeting the duty cycle of Whistler Transit with the continued effort and support of the suppliers. While there have been no apparent nor significant issues related to the fuel cell module and glider components, the propulsion and system integration designed by ISE Corp will remain an ongoing issue.

Fuelling station performance and fuel delivery logistics have been sufficient; however, fuelling times are over twice as long as originally proposed.

There is a need to address a number of performance factors to drive costs down and availability up, if performance is to approach that of incumbent technologies such as diesel buses. This includes the following:

- Improve reliability to reduce the need for contingency buses -due to availability, reliability and fuel range issues in winter months, the operation will likely need to be supplemented with contingency buses

- Reduce maintenance costs through improved reliability and lower component costs - fleet defects still remain (i.e. Eaton compressor) and some of these components are extremely expensive due to their exotic nature

- Reduce fuel costs by reducing fuel consumption to a level that provides the required $450 \mathrm{~km}$ range - system optimization targeted to reliability and bus availability has significantly affected fuel consumption 
- Reduce the cost of hydrogen fuel - on a diesel equivalent basis, the price of hydrogen is over three times more expensive than diesel fuel (based on contract with Air Liquide)

- Design changes to deal with challenging environments - the extreme environment of the RMOW has shown some limitation in the technology

\section{Fuel Cell Technology}

Fuel cells for transit buses are being developed by many developers, who, working with system integrators and bus manufacturers, are supporting a variety of fuel cell transit bus operations at several different locations around the world. Some technical highlights of these fuel cell systems and the transit buses are given below.

- The Ballard FCvelocity®-HD6 delivers $150 \mathrm{~kW}$ (or $75 \mathrm{~kW}$ ) gross power with a system weight of $400 \mathrm{~kg}$ and offers a 12,000-h, 5-year warranty. The system includes air humidification, $\mathrm{H}_{2}$ recirculation, condenser for water management, and CAN and power supply connections.

- The Ballard HD-6+ available in 2014 will offer 24,000-h durability and 15-20\% cost reduction, and HD-7 available in 2015 and later will offer 36,000-h durability and 35$40 \%$ cost reduction.

- The ClearEdge Power PureMotion ${ }^{\mathrm{TM}}$ fuel cell power system delivers $120 \mathrm{~kW}$ net with an efficiency of $>46 \%$ at the rated power. This ambient pressure system has a transient ramp up capability of $24 \mathrm{~kW} / \mathrm{s}$.

- The Hydrogenics HyPM® HD 16 fuel cell system (used in the Proterra battery-dominant fuel cell buses) delivers $16 \mathrm{~kW}$ at a peak net efficiency of $53 \%$, with a transient capability of idle to peak power in less than 5 s. Hydrogenics has also developed 30-, 90-, and 180$\mathrm{kW}$ systems for buses and other heavy-duty applications.

Some technical challenges and progress of ClearEdge Power's PEM power plants are discussed in this section. The fuel cell stack utilizes unique water management strategy, which has been shown to enable higher power density and durability, as compared to solid plate fuel cells. Figure 23 compares porous plate water management technology with that of solid plate fuel cells. Using a porous plate, the reactant gases are humidified internally. Any condensate is also adsorbed by the porous plate, keeping the flow fields clear of any liquid.

Figure 24 shows the fleet operating cycle that is typically seen in any given hour of operation. A typical cycling frequency is $~ 100$ load cycles per hour, with approximately $30 \%$ time spent at an idle condition, or high voltage condition. Load cycling has been shown to exacerbate platinum dissolution and carbon corrosion, inducing performance loss. Since the reactant flows follow the load, the membrane experiences hydration-dehydration cycling, which in turn cause failure, due 
to fatigue. In addition to load cycling, the bus is subjected to frequent start/stop cycles. Both mechanisms have led to early failure of bus power plants.

Three different versions of the Pure Motion $120 \mathrm{~kW}$ cell stacks have been deployed. The performance versus time for each version is shown in Figure 25. The first version, labeled "2006 fleet leader", failed after roughly 1000-1500 hours of operation. For those early units, the bus utilization was relatively low, and the service time was approximately one year. After 10001500 hours of load time, the cell performance dropped rapidly, until the bus could not meet the minimum power requirement and had to be removed from service. Accelerated stress testing (AST) of the cell stack materials revealed that the microporous layer was vulnerable to oxidation. A new microporous layer showed a two-fold improvement in durability in the AST. Changes were made to the system to decrease start/stop losses, as well. After incorporating the new microporous layer and systems changes, the performance decay decreased, but unfortunately, the $2^{\text {nd }}$ version, labeled "2008 fleet leader", failed after 2800 hours, due to membrane failure near the air inlet.

During load cycling, the relative humidity of the gases changes at the reactant inlets. Figure 26 shows model prediction of relative humidity during cycling. Results from mechanical stress modeling, shown in Figure 27, show mechanical stress in the membrane reaches up to $7 \mathrm{MPa}$ during load cycling. During 2800 hours, the fuel cell undergoes over 300,000 of these stress cycles, ultimately failing due to mechanical fatigue.

A more durable membrane was evaluated in a combined membrane mechanical-chemical AST, as shown in Figure 28. The more durable membrane showed at least a 10-fold improvement in durability in the membrane AST. This membrane was deployed in version 3, the "2012 fleet leader". The 2012 fleet leader has reached over 12,000 hours, with a decay rate of $2 \mu \mathrm{V} / \mathrm{hr}$ and no signs of membrane degradation. The bus has been in service for over 5 years.

As mentioned previously, the Whistler Bus demonstration program, the largest fuel cell bus fleet globally, was in service from October 2009 to March 2014. During this time it accumulated more than 3,800,000 km and more than 190,000 hours of operation with 16,000 hydrogen refueling events. This fleet successfully operated on six different routes that include a challenging terrain that included steep up-hill and down-hill driving, encountered ambient temperatures from $-12 \mathrm{C}$ to $27 \mathrm{C}$ that included snowfall from November to May, and salted roads. The buses generally encountered two start-up and shut-down conditions in a 14 hour driving shift.

The dynamic driving conditions with idling at bus stops and traffic lights and start-up/ shut-down conditions generally cause stress on the membrane electrode assembly (MEA) components promoting degradation of the polymer electrolyte membrane and the catalyst layers. Figure 29 presenting the operational profile that was encountered by the Whistler buses, shows the dynamic current profile and corresponding humidity response. 
Overall, the fuel stack performance of the buses met the end of demonstration target of $15 \%$ voltage loss based on the beginning of stack performance. In fact, the stack performance after 9000 hours was still well above the targeted performance loss as shown in Figure 30. MEAs selected from stacks that operated in the field for $\sim 4000$ and 8000 hours were analyzed for membrane and catalyst layer degradation and compared to MEAs that operated in the laboratory. The results, shown in Figure 31, were compared to laboratory stacks that used the same MEA as the Whistler stacks and tested under the same temperature operating conditions and at $100 \% \mathrm{RH}$ using a duty cycle that simulated field operation however, without shut-down/start-up event. The evaluation of membrane thinning, one of the measures of membrane degradation, did not show significant differences between the MEAs operated in field stacks or in the laboratory, nor with the new MEA designs. Thus global membrane thinning has not contributed to the performance degradation. However, some MEAs from both the bus and laboratory stacks the showed evidence of some local pinhole formation. Figure 32 shows a typical IR image of the MEA revealing thin spots and potential pinholes within the membrane. After carefully removing the catalyst layer from the membrane, pinholes and divots were exposed within the membrane which will affect fuel cell performance. This evidence is also supported by the observed leak rate within the stack.

An analysis of the electrochemical catalyst surface area (ECSA) of the cathode catalyst layer, Pt in the membrane, and catalyst layer thickness provides some insight into the catalyst layer degradation mechanisms. The ECSA change, an indication of Pt dissolution and subsequent agglomeration (shown in Figure 33 for the cathode), shows the same trend for stacks operated in the field and those in the laboratory. One might argue that the field returns have somewhat lower ECSA loss which may be associated with the dynamic humidity profile the field stacks experienced (shown in Figure 29), while the ones in the lab operated at a constant RH of $100 \%$. Pt dissolution has been shown to increase with increasing RH operation.

Platinum dissolution also causes Pt to migrate from the cathode into the membrane where it forms a Pt band [19]. Figure 34, a comparison of the Pt in the membrane content of the field operated stacks and those tested in the lab, again shows very little difference however in agreement with the slightly lower ECSA loss, the Pt in the membrane is also slightly lower.

A thinning of the catalyst layer with operation would indicate corrosion of the carbon support of the Pt catalyst due to high cathode voltage excursions experienced during shut-down/start-up operation. As shown in Figure 35 no significant differences in cathode thickness were observed in field operated vs. lab tested labs.

In summary, the voltage loss of the bus stacks is likely at least in part caused by the development of local pin holes in the membrane. While the overall ECSA loss with operation seems substantial, this loss cannot account for the observed performance degradation of the Whistler buses. Small scale laboratory results have shown that for baseline MEAs an ECSA loss of 50\% does not significantly affect fuel cell performance. 
In parallel to technology developed at the fuel cell manufacturers, fuel cell technology for buses has been actively pursued in the academia. Beyond the NFCBP, FTA funds fuel cell bus research at several universities. The research at the universities in North America and Europe has produced improvement in fuel cell technology for electric bus ranging from modeling tools to assist in the design of the supervisory energy management [20] to the development of a hydrogen range extender in hybrid electric bus [21].

\section{Hydrogen Infrastructure}

\subsection{North America}

All of the major industrial gas suppliers have participated in one or more of the fuel cell transit bus demonstration projects. These gas suppliers include Air Liquide, Air Products and Chemicals, Inc. (APCI), and Linde. Fueling station requirements vary by the project and depend on the location, size of the fuel cell bus fleet, and projections for growth at the site and in the region. Examples of fueling station designs in the United States are:

- Proterra fuel cell bus: $66 \mathrm{~kg}$ storage capacity with $120 \mathrm{~kg} /$ day maximum dispensing amount; 7,000 psi off-board storage pressure for 5,000 psi on-board storage system; remote operation and monitoring capability, non-communication-based fast-fill dispensing; and designed for expansion to on-site $\mathrm{H}_{2}$ generation capability.

- The Emeryville, CA, hydrogen fueling station of AC Transit, part of the HyRoad Project that opened in the second half of 2011, offers transit fueling inside the fence, and public fueling outside the fence. Some of the $\mathrm{H}_{2}$ is obtained by electrolysis of water using solar photovoltaic energy.

The Emeryville station is a combined facility for light-duty fuel cell electric vehicles (FCEVs) and FCEBs. Funding from the state of California made the light-duty FCEV fueling access possible - dispensers are available to fuel at 350 and 700 bar pressure.

Figure 36 provides a simple block diagram of the station and primary components. Hydrogen is provided from two sources: liquid hydrogen delivery and a solar-powered electrolyzer. Hydrogen from both sources feeds into high-pressure gaseous storage tubes for fueling buses and autos. The electrolyzer is capable of producing $65 \mathrm{~kg}$ of hydrogen per day. When combined with the liquid hydrogen delivered, the station has the capacity to dispense up to $600 \mathrm{~kg}$ of hydrogen.

The station uses two compressors: one is a high-pressure mechanical compressor and the other is an ionic compressor. The mechanical compressor (MF-90) handles the FCEV side of the station and is capable of filling at both 350 and 700 bar. Linde's ionic compressor (IC-50) handles the bus fueling side of the station. This compressor uses a proprietary ionic liquid in place of a mechanical piston. Ionic liquids are made up of organic salts that remain in a liquid state within a specific temperature range. Composed entirely of particles with negative and positive charges, 
the liquid is nearly incompressible and behaves like a solid material during compression. Using liquid instead of conventional metal pistons means fewer moving parts and no need for lubricants that could cause contamination. This also results in higher operating efficiency. The station also has an emergency dispenser for the buses in case there are issues with the primary fueling dispenser. The buses can be fueled quickly $-30 \mathrm{~kg}$ in about 6 minutes.

Air Liquide has provided $\mathrm{H}_{2}$ for the Project Driveway stations in New York and California, mass transit stations in Whistler, Canada, and Oslo, Norway, and for several materials handling forklift truck applications. Hydrogen supply alternatives include liquid trailer, 200-500-bar tube trailer, and on-site production by SMR or electrolysis. Compression technologies for dispensing include liquid pump and vaporization (1000 kg/day), liquid vaporization and gas compression to 1000 bar, by gas booster for up to $10 \mathrm{~kg} /$ day or by membrane compressor for $100-1000 \mathrm{~kg} / \mathrm{day}$. For transit bus fleets smaller than 25 buses, Air Liquide's analysis indicates that delivered gas is the cheapest option; for larger fleets, SMR may be recommended.

Air Liquide's Vancouver Whistler project for the 20-bus fleet represents one of the world's largest fueling stations. It is capable of fueling 12-15 buses/day at a fill rate of $5 \mathrm{~kg} / \mathrm{min}$, with no limitation on successive fills of up to $50 \mathrm{~kg}$ in about $10 \mathrm{~min}$. Hydrogen is obtained by SMR, liquefied, and shipped by liquid $\mathrm{H}_{2}$ tanker; local back-up is provided by electrolysis. At the fueling station, liquid $\mathrm{H}_{2}$ is stored in two vertical 20,000-gal tanks, each holding $5,300 \mathrm{~kg}$; this stored amount represents 10-12 days of usage at the maximum consumption rate. Equipment integrity is monitored by leak-test instrumentation, gas sensors, and flame detectors. All systems are wired with Emergency Stop push buttons.

Air Products has been involved in $\mathrm{H}_{2}$ energy projects since 1993, with an accumulated experience base of more than $130 \mathrm{H}_{2}$ station projects in 19 countries and over 350,000 fuelings/year. For a 200-bus fleet requiring $25 \mathrm{~kg} /$ fueling, the challenge would be to dispense $5,000 \mathrm{~kg}$ in $6 \mathrm{~h}$, corresponding to an average fill rate of $13.9 \mathrm{~kg} / \mathrm{min}$. Industrial customers, by comparison, are more varied: refinery, 283,000 kg/day, 24/7 demand; large liquid $\mathrm{H}_{2}$ customer, $5,000 \mathrm{~kg} /$ day, 24/7 demand; forklift site, 75-200 kg/day, $1 \mathrm{~kg} /$ fueling in 3-5 min, 25-100 fuelings/day; Space Shuttle, 130,000 kg/launch (program terminated).

Air Products has developed a dual-phase $\mathrm{H}_{2}$ tanker by modifying a liquid $\mathrm{H}_{2}$ tanker to deliver both liquid and gaseous $\mathrm{H}_{2}$ at up to 7,200 psi. This tanker can supply fuel to a liquid $\mathrm{H}_{2} \operatorname{tank}$, off-board bulk $\mathrm{H}_{2}$ storage, a mobile fueler, or tube trailers. This tanker has been deployed in the U. S. and Europe and offers the opportunity to optimize fuel supply logistics and improve fueling economics.

\subsection{Europe}


Details of the new refueling sites deployed as part of CHIC are listed in Table 7. To date, the sites in London, Aargau and Oslo, are fully operational. However, as with the bus performance and reliability data, no data has yet been released from the CHIC project in relation to the performance and reliability of the refueling infrastructure deployed, except for the London deployment where an excellent availability level of over $99 \%$ has been achieved.

Data is available from the CUTE and HyFleet:CUTE projects running from 2003-2009 (> 555 tons of hydrogen dispensed, > 13,000 refuelings, $89.8 \%$ overall station availability, etc.), but this does not represent the state-of-the-art of hydrogen refueling technologies and initial data from the CHIC stations suggest reliability over $98 \%$ is regularly being achieved.

\section{Projections and Targets}

\subsection{United States}

Table 8 lists the 2016 and ultimate targets for fuel cell transit buses. The targets [22] were established by the Department of Energy and the Department of Transportation's Federal Transit Administration in collaboration with private and public entities. The 2013 status of FCEBs performance are also shown for comparison. Several of the technical performance targets have been achieved or nearly achieved. These include fuel economy, range, operation time, maintenance cost, bus availability and roadcall frequency.

Based on industry input, the capital cost of a FCEB, currently at $\$ 2,000,000$, can meet the 2016 target of $\$ 1,000,000$ through a limited production of FCEBs of the same design, while the $\$ 600,000$ target requires high volume manufacturing at fully commercial level [23]. Increasing the durability and reliability of the fuel cell system continues to be a key challenge for manufacturers. The FTA life cycle requirement for a full size bus is 12 years or 500,000 miles. A fuel cell power plant (FCPP) needs to last about half of that time; this is similar to a diesel engine that is typically rebuilt at about mid-life of the bus. DOE/FTA set an ultimate performance target of 4-6 years (or 25,000 hours) durability for the fuel cell propulsion system, with an interim target of 18,000 hours by 2016. Manufacturers have continued to make significant progress toward meeting the target over the last year. As of July 2012, a FCPP manufactured by ClearEdge Power has reached 12,000 hours.

\subsection{Europe}

A number of studies have been undertaken to project the future performance and cost for FCEBs in Europe. The two most relevant and recent studies [24,25] are sponsored by FCH JU and 'Nexthylights', an FCH JU-funded industry collaboration project. The results of these studies are illustrated here. Both the FCH JU and the Hydrogen Bus Alliance have set targets relevant to Europe for a range of performance metrics and these are referenced in the results of the above studies. 


\section{Bus Costs}

The capital cost of the latest generation of hybridized FCEBs deployed in Europe has ranged from approximately $€ 1-1.5 \mathrm{mn}$, as shown in Figure 37 . The cost-down trajectory from earlier trials is consistent with achieving the HBA target of a price range of $€ 400-750 \mathrm{k}$ by 2015 .

However, Figure 38 illustrates industry projections for cost-volume reductions to 2020, in which the 2015 HBA lower target is only realistically expected to be achieved by 2020. It is expected that cost reductions from 2010-2015 will occur as a result of technological improvements and learning lessons, whereas from 2015-2020 cost reductions will rely on the volume of fuel cell systems produced and cross-industry cost-volume reductions from the widespread rollout of FCEVs in the car industry. It is expected that with significant deployment volumes by 2030, the cost of FCEBs will remain $€ 100-200 \mathrm{k}$ higher than conventional diesel buses, and. €50-100k higher than diesel hybrid buses.

\section{Availability}

Availability for hybridized FCEBs is targeted to range from $85-95 \%$ by 2015 , as shown in Figure 39. While this target has already been met for non-hybridized FCEBs (92\% availability during the HyFleet:CUTE project), hybridized FCEB deployments have not yet achieved targeted availabilities, for a range of reasons mainly related to the novelty of hybridized designs, with causes of failure including:

- Failures centered on the hybrid-enabling components, such as power electronics, batteries, control systems and integration issues, rather than the core fuel cell components. These types of issues are expected to improve with each subsequent generation of FCEBs and as learning lessons from the widespread deployment of diesel hybrid buses take effect.

- Lower than expected availability in a number of projects due to early teething problems and immature supply chains for the maintenance of the vehicles. This is expected to improve rapidly as lessons are learned from existing deployments.

\section{Range and fuel economy}

With the recent introduction of the latest generation of hybrid FCEBs with superior fuel efficiency to non-hybridized FCEBs, 2015 range targets of $500 \mathrm{~km}$ are now either being met or within reach, as shown in Figure 40. 
For those buses with insufficient range ability servicing certain more rural routes, the integration of additional hydrogen storage tanks would enable them to achieve their range targets, at the expense of reducing passenger capacity.

In parallel with the increase in range ability of FCEBs, their fuel economy has shown a step change between non-hybridized and the latest hybridized deployments in Europe, improving from $22 \mathrm{~kg} / 100 \mathrm{~km}$ to $10 \mathrm{~kg} / 100 \mathrm{~km}$, as shown in Figure 41.

The best of the latest fuel economy figures already exceed the JTI targets, while the more stringent HBA target of $8 \mathrm{~kg} / 100 \mathrm{~km}$ is expected to be achieved with the next generation of hybridized fuel cell systems.

It must be noted that different drive cycles between projects result in inconsistent results, so a standardized drive cycle testing procedure would benefit the industry in terms of understanding fuel economy performance in greater detail.

\section{Weight}

Weight restrictions are an important factor in the future commercial deployment of FCEBs, with the current range of FCEBs weighing up to 2.5 tons more than a conventional diesel bus. This is likely to cause an issue for busy urban routes where maximizing passenger capacity is a key operational requirement.

However, the weight of FCEBs is expected to converge on the weight of conventional buses as improved efficiencies result in reduced hydrogen storage equipment weight and improved design of the hybridized system result in lower balance-of-plant and other supporting equipment weight.

\section{Summary}

FCEBs have been proven to operate with zero local emissions, reduced noise and reduced emissions on a well-to-wheel basis compared to traditional diesel buses. In addition, FCEBs are significantly more fuel efficient. The performance data for FCEBs deployed in demonstration projects in North America and Europe is improving substantially over time. Some technical targets for commercialization have been met or are within reach. These include fuel economy, range, availability, operation time, MBRC and maintenance cost. The main barriers for FCEBs, compared to conventional diesel buses, are a lack of infrastructure for refueling, the high bus capital cost and meeting a fuel cost of $\$ 5-7$ per $\mathrm{kg} \mathrm{H}_{2}$ [25] at which price the fuel cost per mile will be competitive with conventional buses. These challenges are being addressed in demonstration projects globally. 


\section{Acknowledgments}

This work was supported by the U.S. Department of Energy's Office of Energy Efficiency and Renewable Energy. Argonne National Laboratory, a U.S. Department of Energy Office of Science laboratory, is operated by UChicago Argonne, LLC, under Contract No. DE-AC0206CH11357. The authors acknowledge the contribution of the Advanced Fuel Cells Implementing Agreement, IEA, from which this paper results, specifically the activities of Annex 26: Fuel Cells for Transportation. Please see www.ieafuelcells.com for more information.

\section{References}

1. L. Eudy and K. Chandler, "Zero Emission Bay Area (ZEBA) Fuel Cell Bus Demonstration: Second Results Report," NREL Technical report, NREL/TP-560055367, July 2012

2. R. Zaetta and B. Madden, "Hydrogen Fuel Cell Bus Technology State of the Art Review," NextHyLights Report, Version 3.1, Feb 2011

3. International Fuel Cell Bus Collaborative, http://gofuelcellbus.com/index.php/thecollaborative/all-active-demonstrations

4. L Eudy and C. Gikakis, "Fuel Cell Buses in U.S. Transit Fleets: Current Status 2013," NREL Technical report, NREL/TP-5400-60490, December 2013

5. L. Jerram, "Fuel cell Buses in Perspective: International Program and the Global Transit Bus Market," National Fuel Cell Bus Workshop, October 2011

6. See http://chic-project.eu/

7. See http://highvlocity.eu/

8. See http://busonline.ca/fuelcell/fleet.cfm

9. T. Ikeda, "FCV/Infrastructure Demonstration Program in Japan," IEA Advanced Fuel Cells Annex 26 Workshop, May 14, 2013

10. See Hyundai press release, http://worldwide.hyundai.com/WW/Corporate/News/News/DF_GT_GLOBALNEW

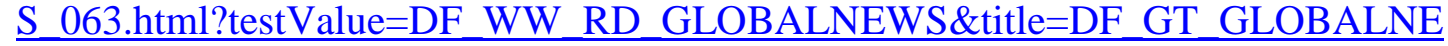
WS_063\&selx2=

11. R. Lin, X. Pan, and X. Li, "Chinese Hydrogen and Fuel Cell Activities in 20102011," International Partnership for Hydrogen and Fuel Cells in the Economy Joint SC/ILC Meeting, Vancouver, Canada, May 2011

12. Ballard press release http://www.ballard.com/about-ballard/newsroom/newsreleases/news09261301.aspx 
13. Ballard press release http://www.ballard.com/about-ballard/newsroom/newsreleases/news12271101.aspx

14. Ballard press release http://www.ballard.com/about-ballard/newsroom/newsreleases/news01271201.aspx

15. K. Chandler and L. Eudy, "FTA Fuel Cell Bus Program: Research Accomplishments through 2011," FTA Report No. 0014, March 2012

16. McKinsey Global GHG Abatement Cost Curve; International Energy Agency World Energy Outlook 2009; US Environmental Protection Agency; European Environment Agency (EEA)

17. HyFleet:CUTE, A Report on the Achievements and Learnings from The HyFleet:CUTE Project 2006-2009. http://hyfleetcute.com/data/HyFLEETCUTE_Brochure_Web.pdf

18. Ballard, http://www.ballard.com/fuel-cell-applications/bus.aspx

19. T. Cheng, E. Rogers, A. Young, S. Ye, V. Colbow, and S. Wessel, "Effect of Crossover Hydrogen on Platinum Dissolution and Agglomeration," J. Power Sources 196 (2011) 7985- 7988

20. K. Simmons, Y. Guezennex, and S. Onori, "Modeling and Energy Management Control Design for a Fuel Cell Hybrid Passenger Bus," J. Power Sources 246 (2014) $736-746$.

21. F. Sergi, L. Andaloro, G. Napoli, N. Randazzo, and V. Antonucci, "Development and Realization of a Hydrogen Range Extender Hybrid City Bus," J. Power Sources 246 (2014)

22. U.S. DOE Fuel Cell Bus Targets. http://www.hydrogen.energy.gov/pdfs/12012_fuel_cell_bus_targets.pdf

23. “A Road Map for Fuel Cell Electric Buses in California,” California Fuel Cell Partnership, March 2013. http://cafcp.org/sites/files/A_Roadmap_for_Fuel_Cell_Electric_Buses_in_California _FINAL.pdf

24. "Building a Commercially Viable National Fuel Cell Electric Bus Program," Fuel Cell and Hydrogen Energy Association, March 2011. http://cafcp.org/sites/files/Building\%20a\%20Commercially\%20Viable\%20National \%20Fuel\%20Cell\%20Transit\%20Bus\%20Program.FINAL_.v10.03-25-11.pdf

25. "Urban Buses: Alternative Powertrain for Europe". http://www.fchju.eu/sites/default/files/20121029\%20Urban\%20buses, \%20alternative\%20powertrain s\%20for\%20Europe\%20-\%20Final\%20report_0.pdf 
Table 1. Active fuel cell bus projects globally [3].

\begin{tabular}{|c|c|c|c|c|c|}
\hline \multirow{2}{*}{$\begin{array}{c}\text { Site, } \\
\text { Country }\end{array}$} & \multirow{2}{*}{$\begin{array}{c}\text { Fleet } \\
\text { Size }\end{array}$} & \multirow{2}{*}{$\begin{array}{l}\text { Project/ } \\
\text { Operator }\end{array}$} & \multirow{2}{*}{$\begin{array}{l}\text { Start } \\
\text { Date }\end{array}$} & \multicolumn{2}{|c|}{ Manufacturer } \\
\hline & & & & Bus & Fuel Cell \\
\hline Bay Area, USA & 12 & AC Transit & 2011 & Van Hool & ClearEdge \\
\hline Hartford, USA & 4 & CTTransit & 2007 & Van Hool & ClearEdge \\
\hline Thousand Palms, USA & 1 & Sunline & 2011 & New Flyer & Ballard \\
\hline Thousand Palms, USA & 1 & Sunline & 2011 & ElDorado & Ballard \\
\hline Austin, USA & 1 & Capital Metro/UT & 2012 & Proterra & Hydrogenics \\
\hline Burbank, USA & 1 & Burbank Bus & 2010 & Proterra & Hydrogenics \\
\hline San Francisco, USA & 1 & SF Metro Transit & 2010 & Daimler & Hydrogenics \\
\hline Newark, USA & 2 & U of Delaware & 2007 & Ebus & Ballard \\
\hline New Haven, USA & 1 & GNHTD & & Ebus & Ballard \\
\hline Lewis-McChord, USA & 1 & Dept of Defense & & Proterra & Hydrogenics \\
\hline Barth, Germany & 1 & Osteebus & 2006 & Neoplan & Proton \\
\hline Hamburg, Germany & 4 & CHIC, CEP & 2011 & Daimler & AFCC \\
\hline Cologne, Germany & 2 & CHIC, HyCologne & 2011 & APTS & Ballard \\
\hline London, UK & 8 & $\mathrm{CHIC}$ & 2011 & Wrightbus & Ballard \\
\hline Oslo, Norway & 5 & $\mathrm{CHIC}$ & 2012 & Van Hool & Ballard \\
\hline Aargau, Switzerland & 5 & $\mathrm{CHIC}$ & 2011 & Daimler & AFCC \\
\hline Milan, Italy & 3 & $\mathrm{CHIC}$ & 2011 & Daimler & AFCC \\
\hline Bolzano, Italy & 5 & $\mathrm{CHIC}$ & 2013 & Daimler & AFCC \\
\hline San Remo, Italy & 5 & High V-LO City & 2013 & Van Hool & Ballard \\
\hline Aberdeen, Scotland & 10 & High V-LO City & 2014 & Van Hool & Ballard \\
\hline Antwerp, Belgium & 5 & High V-LO City & 2014 & Van Hool & Ballard \\
\hline Cologne & 2 & HyCologne & 2014 & Van Hool & Ballard \\
\hline Hamburg & 2 & NOW, Hamburg & 2014 & Solaris & Ballard \\
\hline BC, Canada & 20 & BC Transit & 2010 & New Flyer & Ballard \\
\hline Gladbeck, Germany & 1 & NA & 2010 & Rampini & Hydrogenics \\
\hline Amsterdam, NL & 2 & GVB & 2011 & APTS & Ballard \\
\hline Neratovice, Czech & 1 & TriHyBus & 2009 & Skoda Irisbus & Proton \\
\hline
\end{tabular}




\begin{tabular}{|l|l|c|c|cc|} 
Centrair airport, Japan & 2 & CSS & 2006 & Toyota & Toyota \\
Haneda airport, Japan & 2 & Airport Transit & 2010 & Toyota & Toyota \\
Toyota City, Japan & 1 & Meitetsu & 2010 & Toyota & Toyota \\
\hline
\end{tabular}


Table 2. Selected specifications of the FCEBs at four transit agencies

\begin{tabular}{|l|c|c|c|c|c|}
\hline & ACT ZEBA & CTT Nutmeg & SL AT & SL AFCB & TX Proterra \\
\hline Transit agency & AC Transit & CTTRANSIT & SunLine & SunLine & Capital Metro \\
Number of buses & 12 & 4 & 1 & 1 & 1 \\
Bus OEM & Van Hool & Van Hool & New Flyer & ElDorado & Proterra \\
Bus length (ft) & 40 & 40 & 40 & 40 & 35 \\
Fuel cell OEM & ClearEdge & ClearEdge & Ballard & Ballard & Hydrogenics \\
Fuel cell power (kW) & 120 & 120 & 150 & 150 & $16(x 2)$ \\
Hybrid system integrator & Van Hool & Van Hool & Bluways & BAE Systems & Proterra \\
Design strategy & FC dominant & FC dominant & FC dominant & FC dominant & Battery \\
Energy storage OEM & EnerDel & EnerDel & Valence & A123 & Altairnano \\
Energy storage type & Li-ion & Li-ion & Li-ion & Li-ion & Li-titanate \\
Energy storage power & $21 \mathrm{kWh}$ & $21 \mathrm{kWh}$ & $47 \mathrm{kWh}$ & $11 \mathrm{kWh}$ & $54 \mathrm{kWh}$ \\
H2 storage pressure (psi) & 5,000 & 5,000 & 5,000 & 5,000 & 5,000 \\
Hydrogen cylinders & 8 & 8 & 6 & 8 & 4 \\
Hydrogen capacity (kg) & 40 & 40 & 43 & 50 & 29 \\
\hline
\end{tabular}


Table 3. Miles and hours for the fuel cell buses

\begin{tabular}{|l|c|c|c|c|c|c|c|}
\hline \multicolumn{1}{|c|}{ ID } & Period & Months & $\begin{array}{c}\text { No. of } \\
\text { Buses }\end{array}$ & Miles & Hours & $\begin{array}{c}\text { Speed } \\
\text { (mph) }\end{array}$ & $\begin{array}{c}\text { Monthly } \\
\text { Miles }\end{array}$ \\
\hline ACT ZEBA & $3 / 13-7 / 13$ & 5 & 12 & 156,789 & 18,251 & 8.6 & 2,613 \\
CTT Nutmeg & $8 / 12-1 / 13$ & 6 & 4 & 24,479 & 1,914 & 12.8 & 1,020 \\
SL AT & $8 / 12-7 / 13$ & 12 & 1 & 9,340 & 906 & 10.3 & 778 \\
SL AFCB & $8 / 12-7 / 13$ & 12 & 1 & 36,339 & 2,380 & 15.3 & 3,028 \\
TX Proterra & $10 / 12-3 / 13$ & 6 & 1 & 1,374 & N/A & NA & 229 \\
\hline
\end{tabular}


Table 4. Availability of the fuel cell buses

\begin{tabular}{|l|c|c|c|c|c|c|}
\hline \multicolumn{1}{|c|}{ ID } & Period & Months & $\begin{array}{c}\text { No. of } \\
\text { Buses }\end{array}$ & $\begin{array}{c}\text { planned } \\
\text { Days }\end{array}$ & $\begin{array}{c}\text { Days } \\
\text { Avail. }\end{array}$ & $\begin{array}{c}\% \\
\text { Avail. }\end{array}$ \\
\hline ACT ZEBA & $3 / 13-7 / 13$ & 5 & 12 & 1,486 & 1,209 & 81 \\
CTT Nutmeg & $8 / 12-1 / 13$ & 6 & 4 & 437 & 222 & 51 \\
SL AT & $8 / 12-7 / 13$ & 12 & 1 & 280 & 88 & 31 \\
SL AFCB & $8 / 12-7 / 13$ & 12 & 1 & 331 & 247 & 75 \\
TX Proterra & $10 / 12-3 / 13$ & 6 & 1 & 82 & 46 & 56 \\
\hline
\end{tabular}


Table 5. Active FCEBs in Europe

\begin{tabular}{|lc|lc|lc|lc|}
\hline \multicolumn{2}{|c|}{ CHIC } & \multicolumn{2}{c|}{ High V.LO-City } & \multicolumn{2}{c|}{ HyTransit } & \multicolumn{2}{c|}{ Independent } \\
\hline Location & Buses & Location & Buses & Location & Buses & Location & Buses \\
\hline \hline Aargau & 5 & Aberdeen & 4 & Aberdeen & 6 & Amsterdam & 2 \\
Bolzano & 5 & Antwerp & 5 & & & Amhem & 1 \\
Cologne & 2 & Liguria & 5 & & & Barth & 1 \\
Hamburg & 4 & & & & & Dusseldorf & 2 \\
London & 8 & & & & & Hamburg & 1 \\
Milano & 3 & & & & & Neratovice & 1 \\
Oslo & 3 & & & & & & \\
\hline
\end{tabular}


Table 6. Key performance data from January 2011 through May 2012

\begin{tabular}{|l|c|c|}
\hline Parameter & Unit & Value \\
\hline Jan 2001 to May 2002 & $\mathrm{km}$ & \\
Fleet Accumulated Mileage & $\mathrm{km}$ & $2,189,974$ \\
Bus Average Accumulated Mileage & tons & 3,202 \\
$\mathrm{CO}_{2}$ Emission Avoided & $\mathrm{kg}$ & 549,143 \\
Hydrogen Delivered to Station & $\mathrm{kg}$ & 316,486 \\
Hydrogen Dispensed to Buses & & \\
\hline April 2011 to May 2012 & $\mathrm{kg} / 100 \mathrm{~km}$ & 15.3 \\
Average Fuel Economy & $\$ / \mathrm{km}$ & 1.0 \\
Maintenance Cost & $\mathrm{km}$ & 366 \\
Average Range & $\%$ & 71 \\
Average Bus Availability & $\mathrm{km}$ & 2,740 \\
Mean Distance Between Road Call & $\$ / \mathrm{km}$ & 2.28 \\
Hydrogen Fuel Cost & $\$ / \mathrm{kg}$ & 15.37 \\
& $\mathrm{~kg} / \mathrm{min}$ & 2.2 \\
\hline
\end{tabular}


Table 7. List of new hydrogen refueling infrastructure deployed in Phase $1 \mathrm{CHIC}$ cities

\begin{tabular}{|c|c|c|c|c|}
\hline $\begin{array}{l}\text { Phase } 1 \\
\text { Partners }\end{array}$ & $\begin{array}{l}\text { Pre-existing fueling } \\
\text { infrastructure }\end{array}$ & Capacity & $\begin{array}{l}\text { Second fueling } \\
\text { infrastructure }\end{array}$ & Capacity \\
\hline London & $\begin{array}{l}\text { Delivered liquid - Air } \\
\text { Products }\end{array}$ & $320 \mathrm{~kg} / \mathrm{day}$ & $\begin{array}{l}\text { High pressure tube } \\
\text { trailer }\end{array}$ & $100 \mathrm{~kg} / \mathrm{day}$ \\
\hline Bolzano & Delivered hydrogen & $\begin{array}{l}\text { Delivered } \\
\text { hydrogen }\end{array}$ & $\begin{array}{l}\text { Electrolyzer to be } \\
\text { procured }\end{array}$ & $500 \mathrm{~kg} / \mathrm{day}$ \\
\hline $\begin{array}{l}\text { Aargau/ St. } \\
\text { Gallen }\end{array}$ & Not required & & $\begin{array}{l}\text { Electrolyzer to be } \\
\text { procured }\end{array}$ & $200 \mathrm{~kg} / \mathrm{day}$ \\
\hline Milan & Reformer & 30 kg/day & $\begin{array}{c}\text { Electrolyzer to be } \\
\text { procured }\end{array}$ & $200 \mathrm{~kg} / \mathrm{day}$ \\
\hline Oslo & Delivered hydrogen & $22 \mathrm{~kg} /$ day & $\begin{array}{l}\text { Delivered hydrogen or } \\
\text { Electrolyzer to be } \\
\text { procured }\end{array}$ & $200 \mathrm{~kg} / \mathrm{day}$ \\
\hline
\end{tabular}


Table 8. 2013 DOE/DOT/FTA performance, cost, and durability targets for fuel cell transit buses

\begin{tabular}{|l|c|c|c|c|}
\hline & Units & 2013 Status & 2016 Target & Ultimate Target \\
\hline Bus Lifetime & years/miles & $5 / 100,000$ & $12 / 500,000$ & $12 / 500,000$ \\
Power Plant Lifetime & hours & $1000-12000$ & 18,000 & 25,000 \\
Bus Availability & $\%$ & $53-84$ & 85 & 90 \\
Fuel Fills & per day & 1 & $1(<10 \mathrm{~min})$ & $1(<10 \mathrm{~min})$ \\
Bus Cost & $\$$ & $2,000,000$ & $1,000,000$ & 600,000 \\
Power Plant Cost & $\$$ & 700,000 & 450,000 & 200,000 \\
Hydrogen Storage Cost & $\$$ & 100,000 & 75,000 & 50,000 \\
MBRC, Bus & miles & $2,000-3,500$ & 3,500 & 4,000 \\
MBRC, Fuel Cell System & miles & $7,000-20,000$ & 15,000 & 20,000 \\
Operation Time & h/d, d/week & $19 / 7$ & $20 / 7$ & $20 / 7$ \\
Maintenance Cost & $\$ /$ mile & $0.39-1.30$ & 0.75 & 0.4 \\
Range & miles & $220-325$ & 300 & 300 \\
Fuel Economy & mpgde & $6-7.5$ & 8 & 8 \\
\hline
\end{tabular}




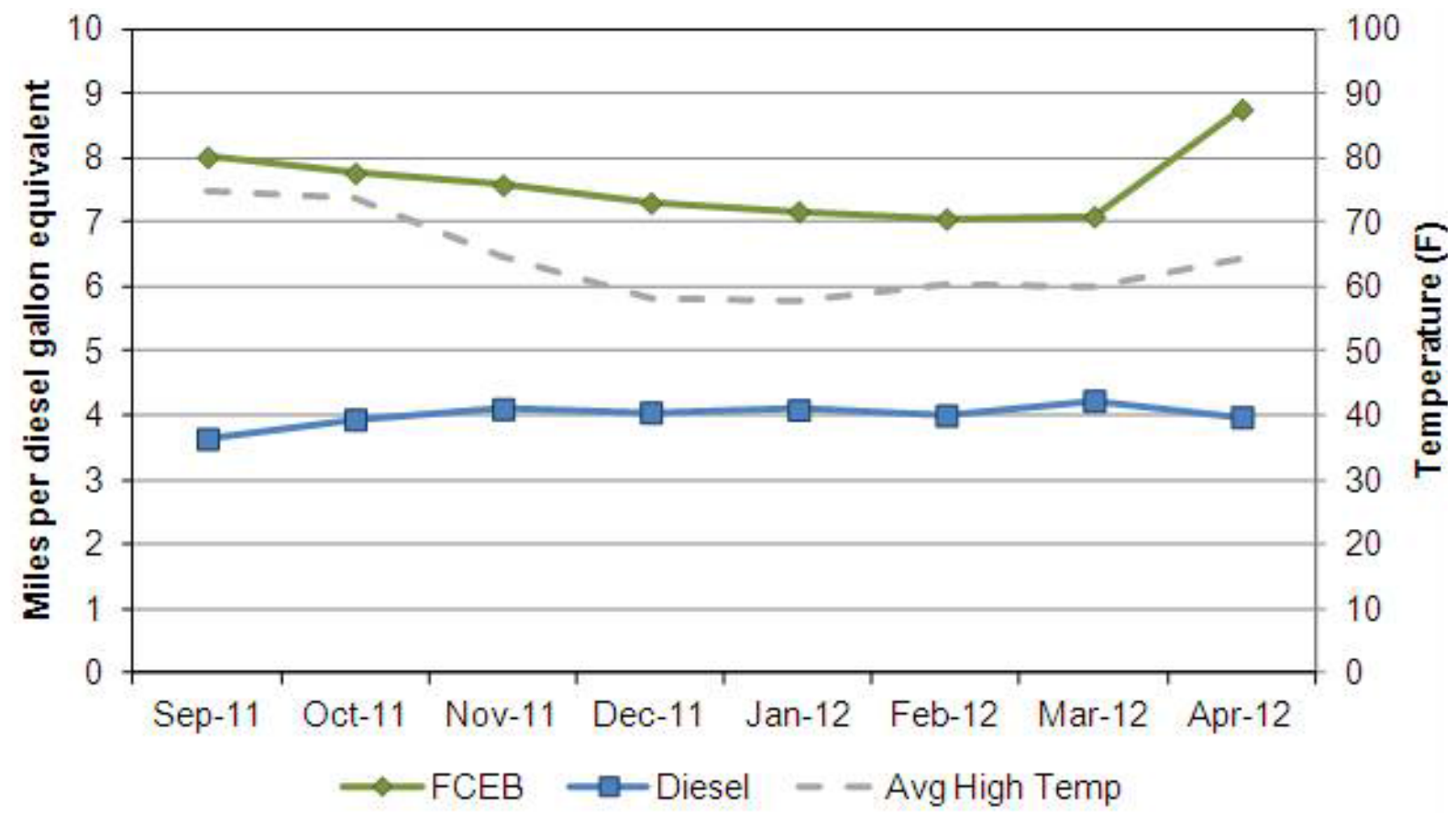

Figure 1. Average fuel economy for the fuel cell and diesel buses [1] 


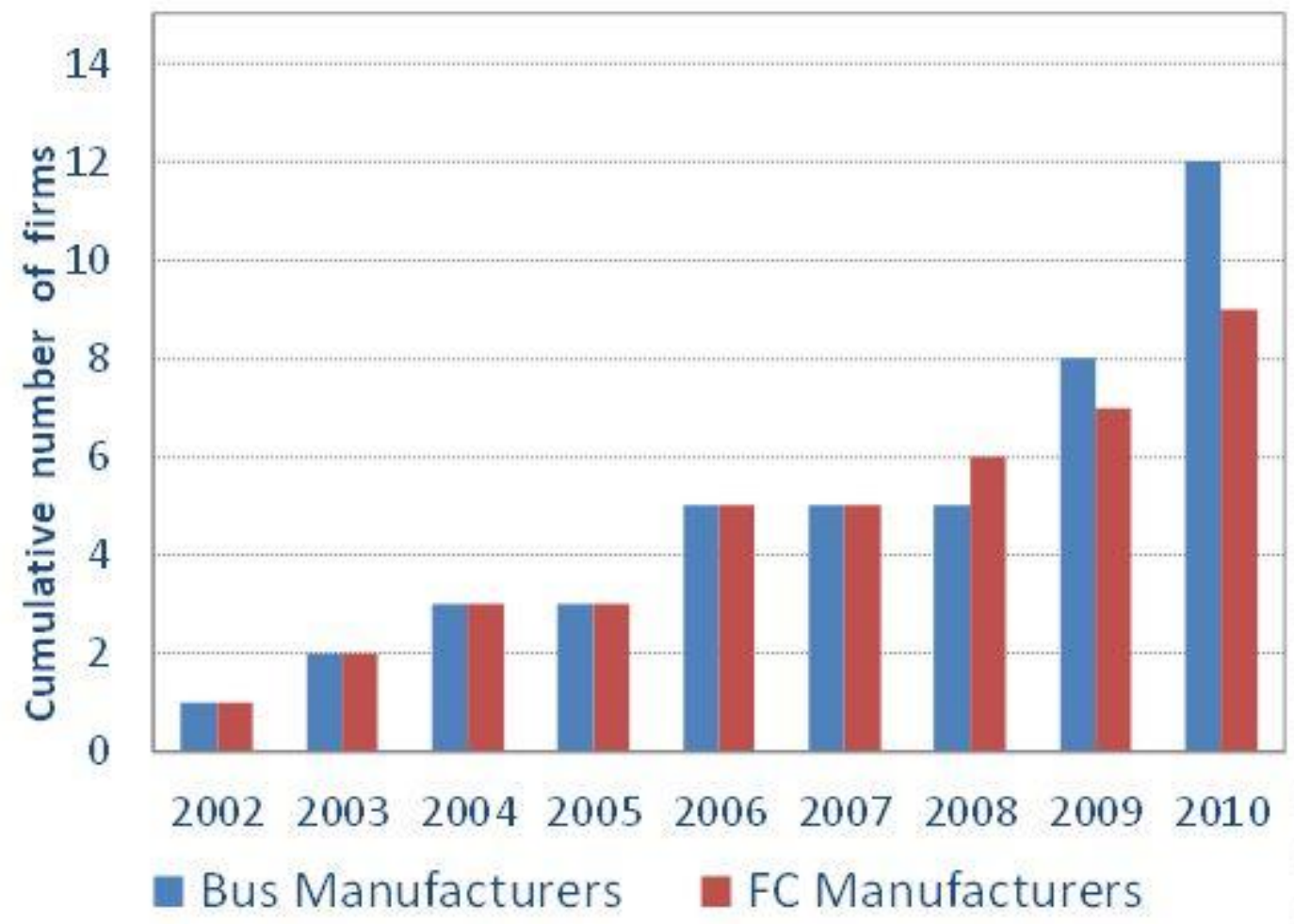

Figure 2. Number of competitors in the fuel cell bus market [2] 


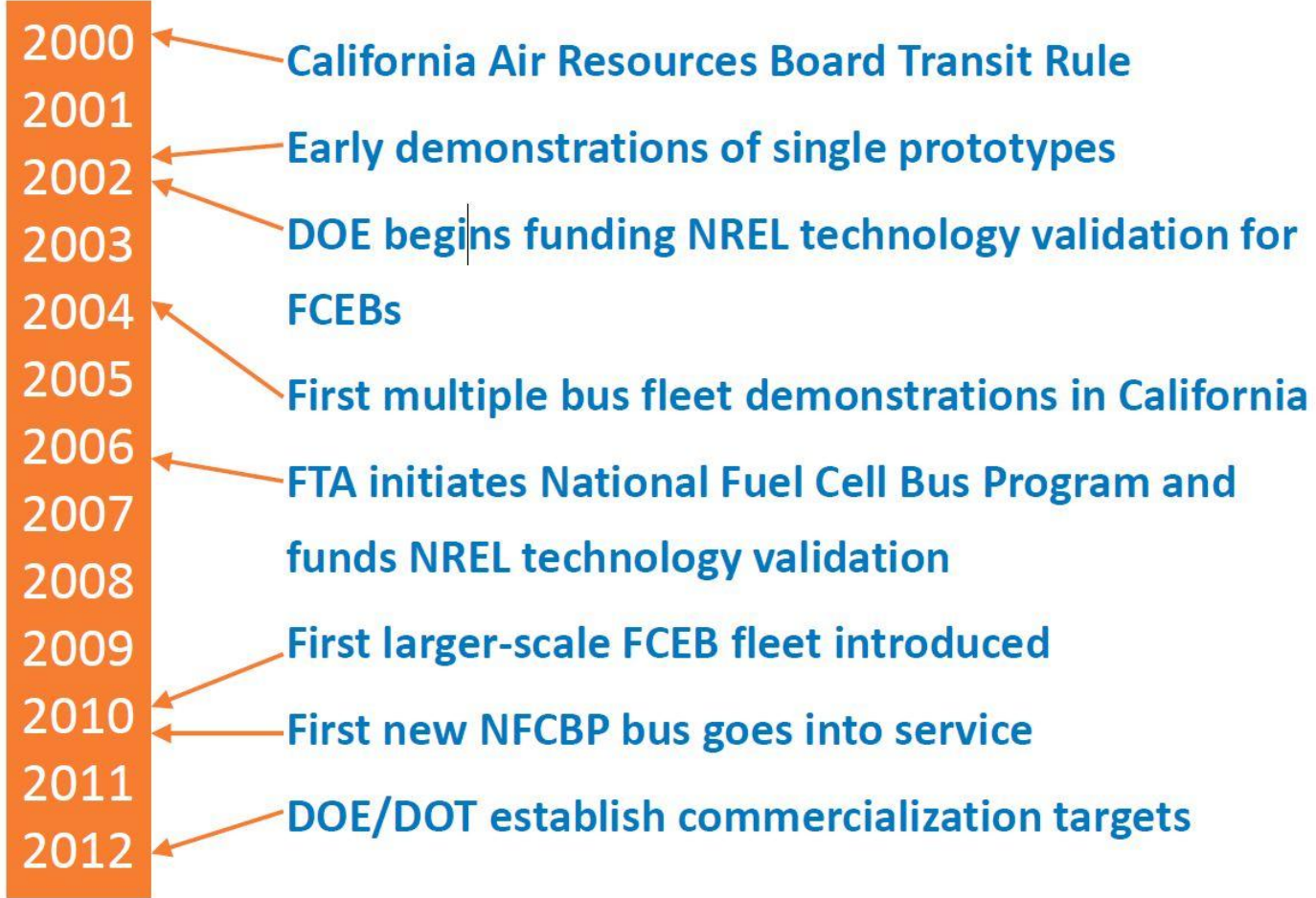

Figure 3. Timeline in the development of FCEB in the United States 


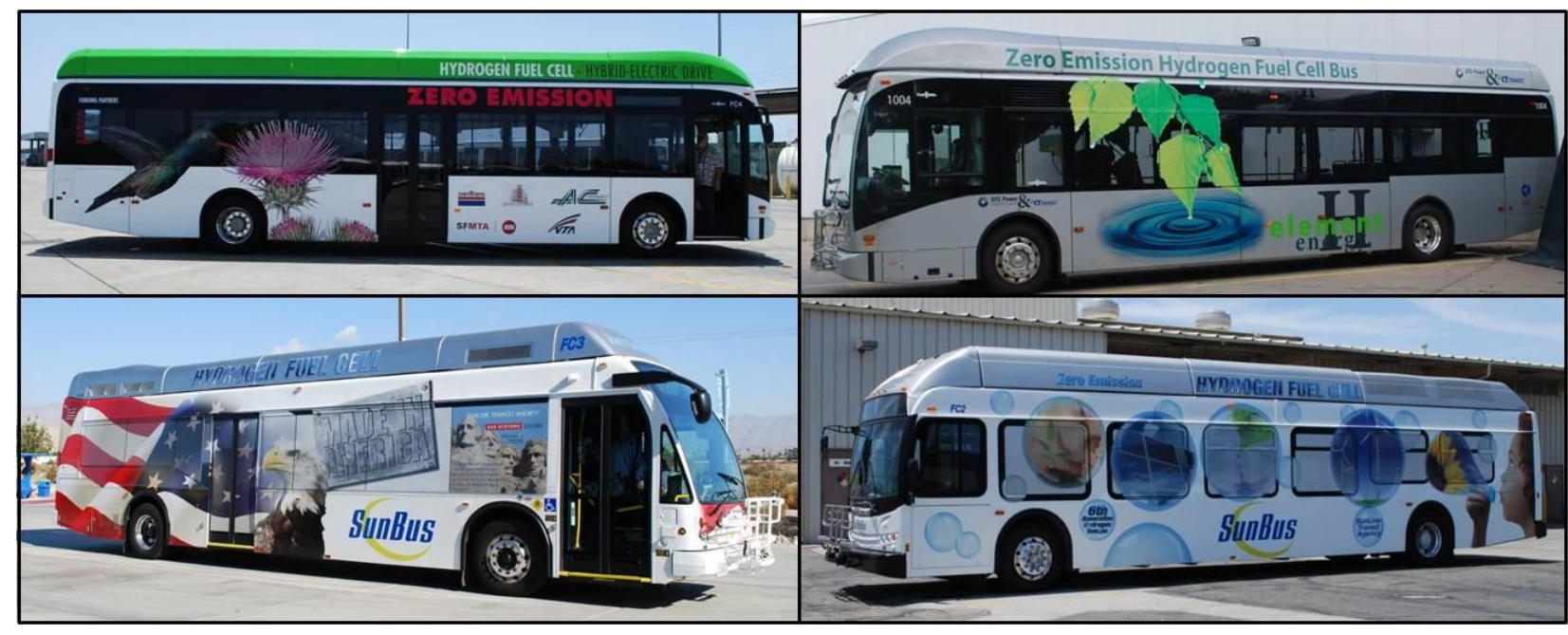

Figure 4. FCEBs included in the data summary: AC Transit ZEBA (top left), CTTRANSIT Nutmeg (top right), SunLine AFCB (bottom left), SunLine AT (bottom right) 


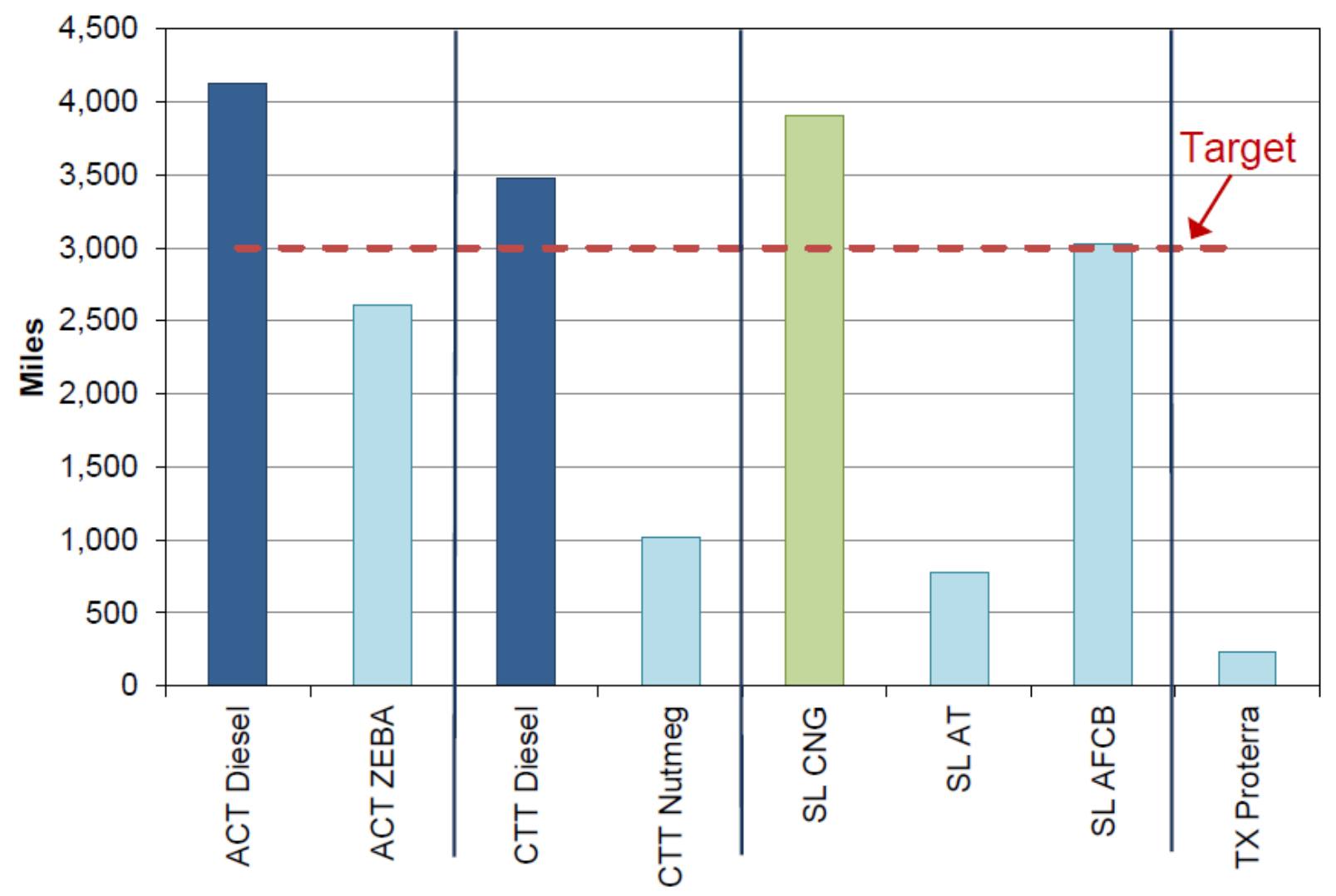

Figure 5. Average monthly miles per fuel cell and baseline buses 


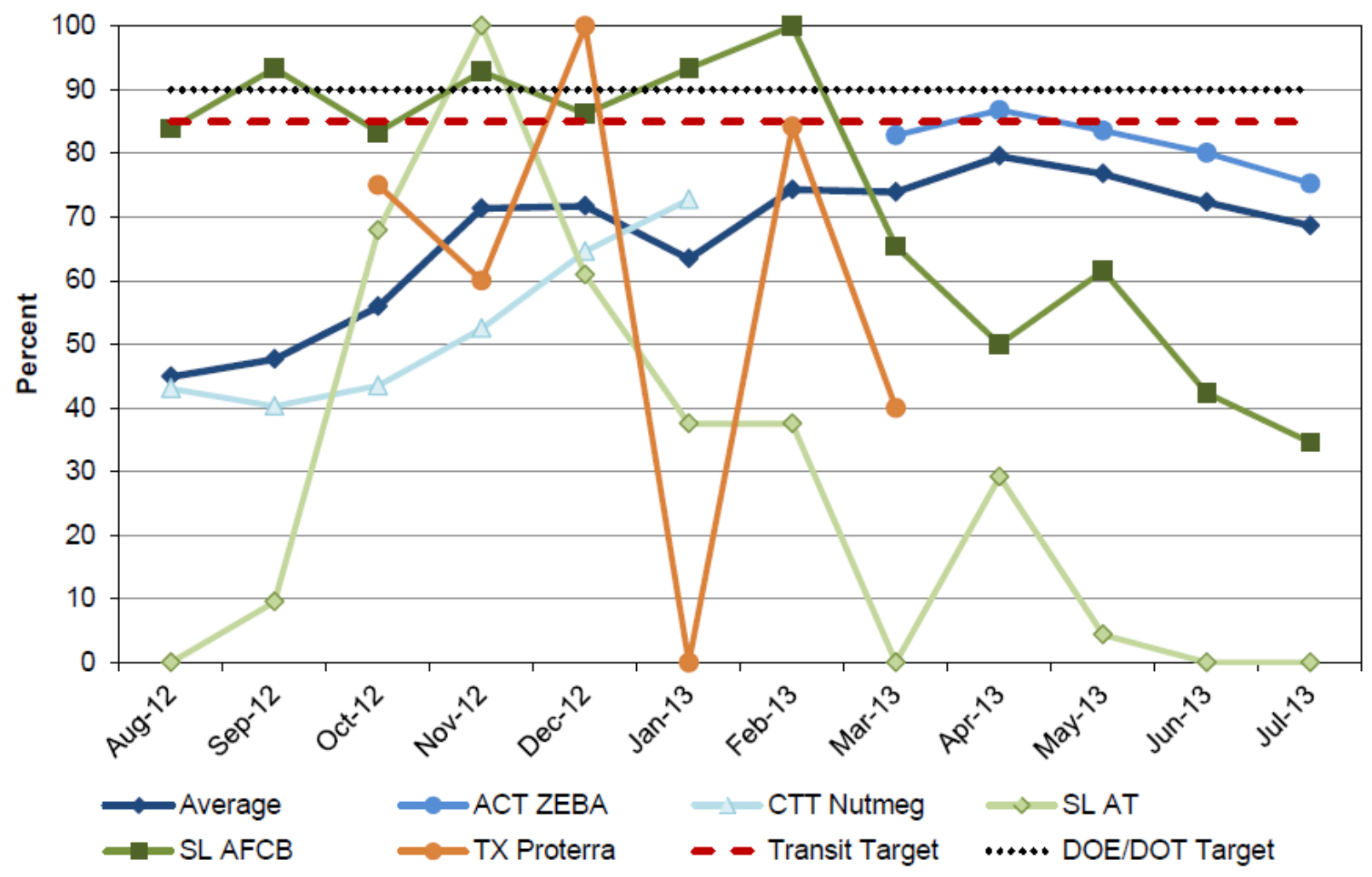

Figure 6. Monthly availability for the FCEBs 


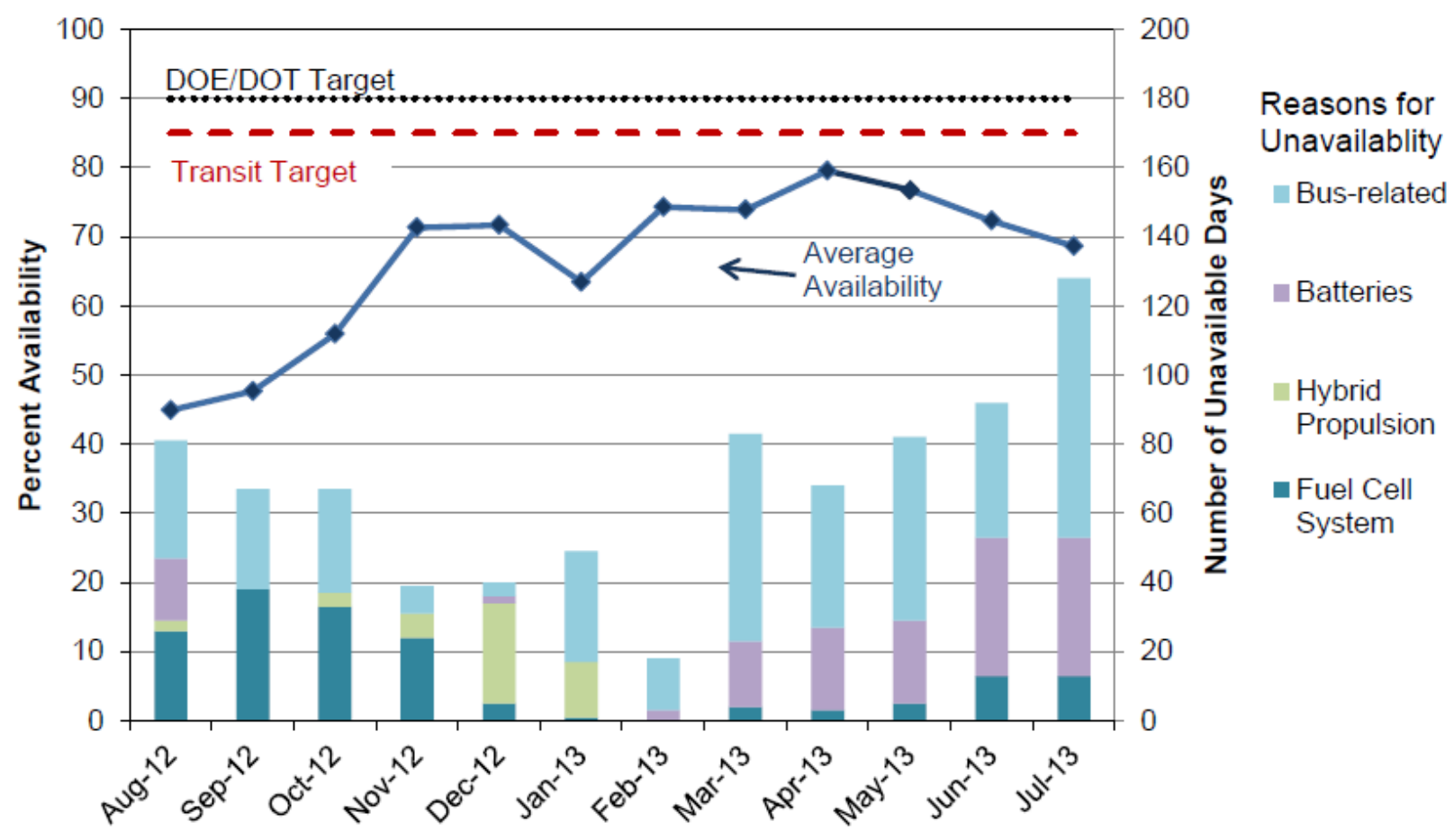

Figure 7. Average monthly availability and number of unavailability days by category 


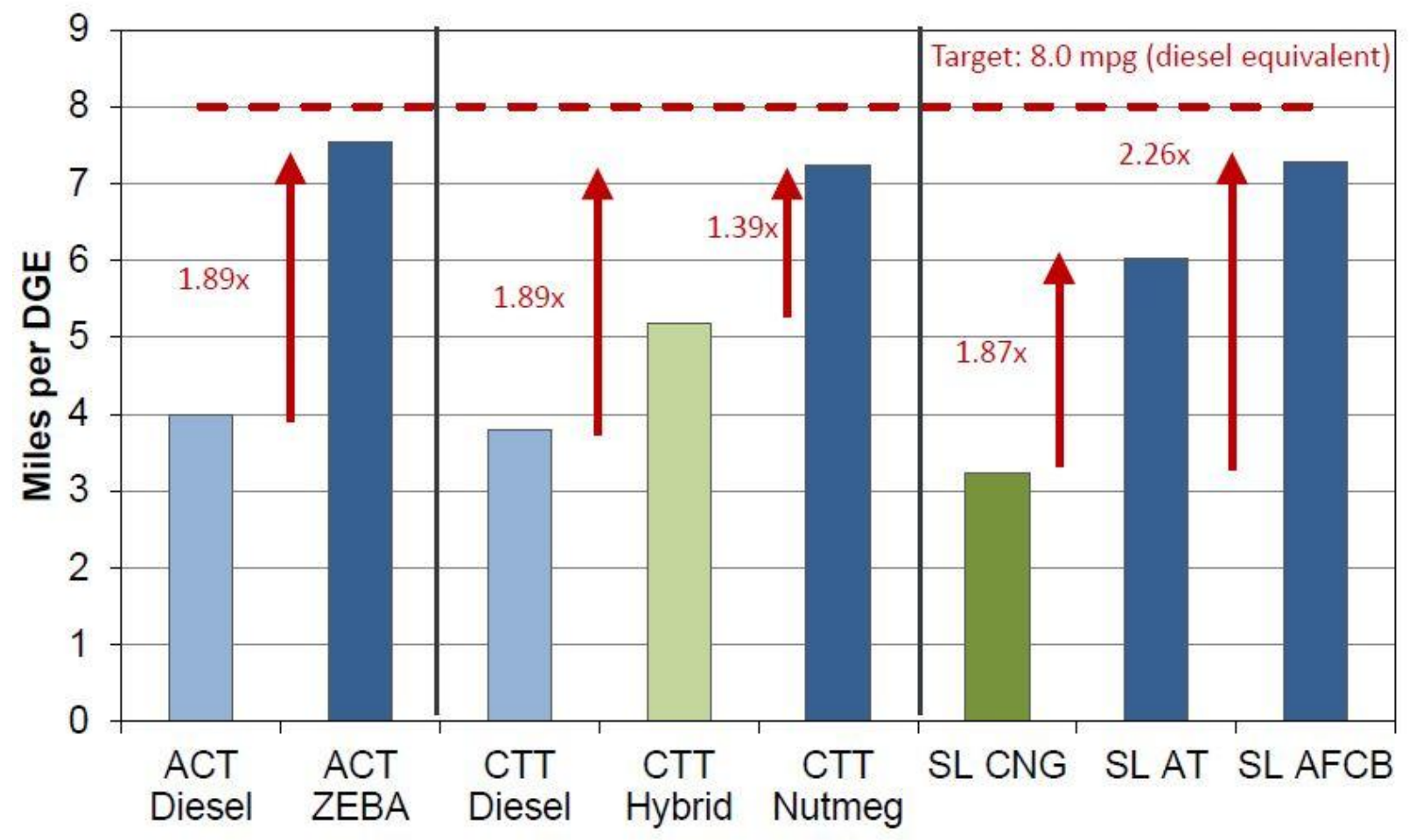

Figure 8. Average fuel economy comparisons between FCEBs and baseline buses 


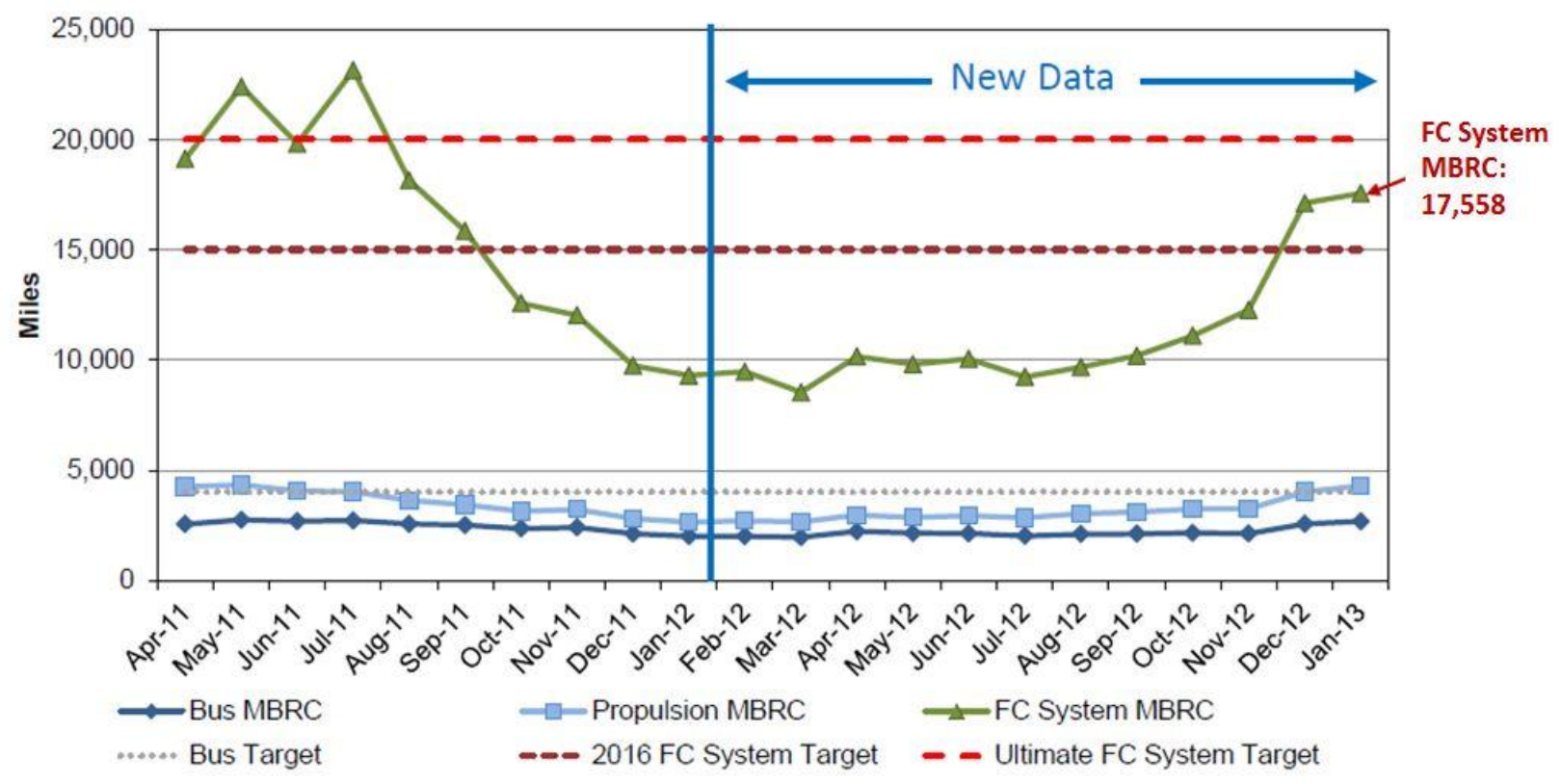

Figure 9. MBRC rates for fuel cell buses compared to the targets 


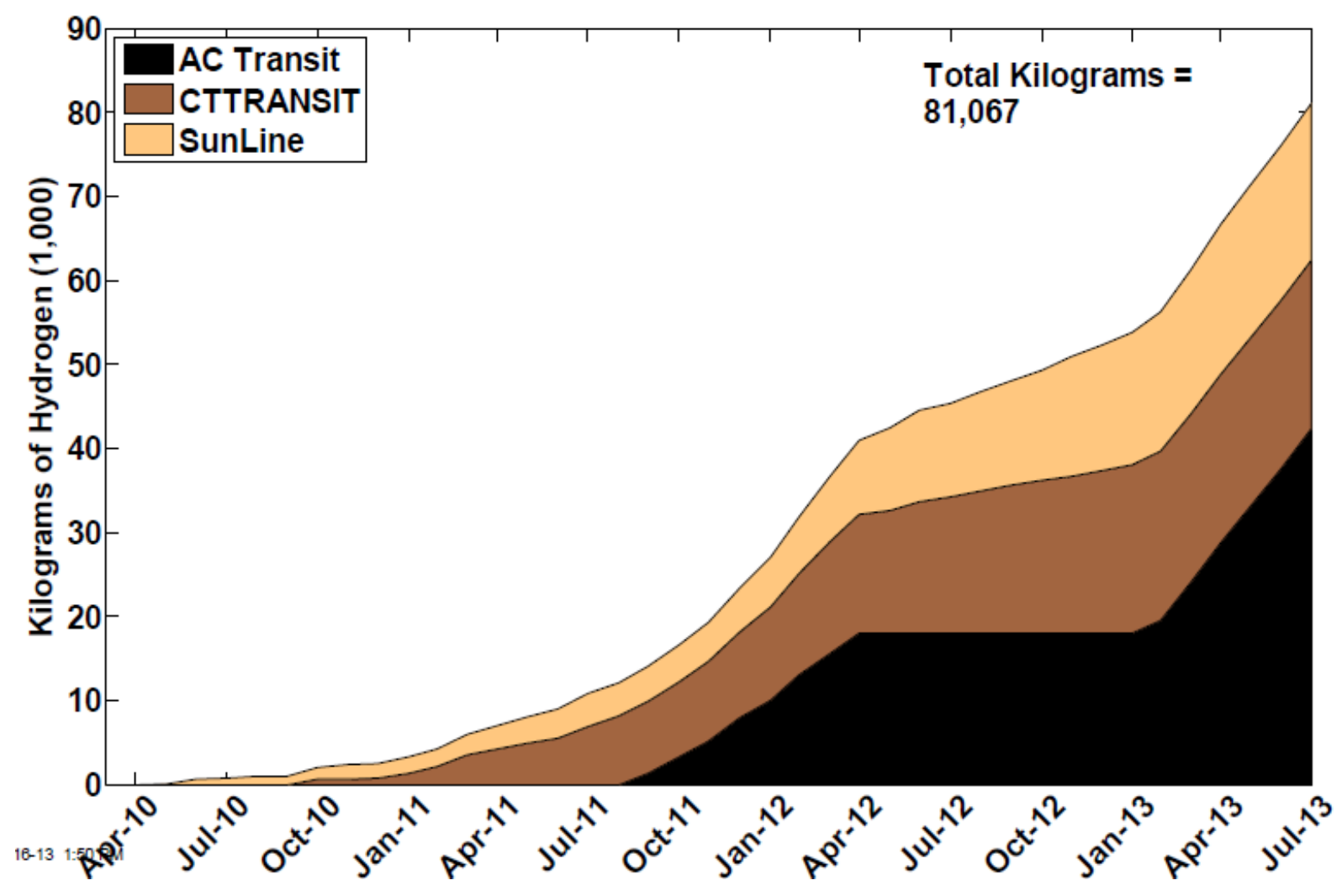

Figure 10. Hydrogen dispensed for the FCEBs at the four demonstrations 


\begin{tabular}{|c|c|c|c|c|c|c|}
\hline & Facts as of 2012 for & Western Europe (12 & $2-m$ and $18-m$ buses & & & \\
\hline & $\begin{array}{l}\text { Diesel/CNG/ } \\
\text { trolley }\end{array}$ & Diesel hybrids $^{1}$ & $\begin{array}{l}\text { Hydrogen } \\
\text { fuel cell bus }\end{array}$ & Opportunity e-bus & Overnight e-bus ${ }^{3}$ & \\
\hline $\begin{array}{l}\text { Number of buses } \\
\text { deployed }\end{array}$ & & $>1,000$ & $>30$ & $0^{3}$ & & $0^{4}$ \\
\hline $\begin{array}{l}\text { Number of } \mathrm{Km} \\
\text { driven }\end{array}$ & $\begin{array}{l}\text { Diesel, CNG and } \\
\text { trolley buses are }\end{array}$ & $>>10,000,000$ & $\begin{array}{r}>1,000,000 \\
(>5,000,000)^{2}\end{array}$ & $0^{3}$ & & $0^{4}$ \\
\hline $\begin{array}{l}\text { Recharging/ } \\
\text { refuelling proce- } \\
\text { dures completed }\end{array}$ & $\begin{array}{l}\text { considered fully } \\
\text { mature as they } \\
\text { have been in use } \\
\text { for }>50 \text { years and }\end{array}$ & Same as diesel & $>500$ & $0^{3}$ & & $0^{4}$ \\
\hline $\begin{array}{l}\text { Number of years } \\
\text { in operation }\end{array}$ & $\begin{array}{l}\text { cover }>95 \% \text { of the } \\
\text { current market (for }\end{array}$ & $\sim 2-3$ years & $\sim 2$ years & $\begin{array}{l}\text { - No operation yet fo } \\
\sim 2 \text { years for } 8-\mathrm{m} \text { or }\end{array}$ & $\begin{array}{l}\text { r } 12-m / 18-m \text { buses } \\
\text { vernight e-buses }\end{array}$ & \\
\hline $\begin{array}{l}\text { Supply industryl } \\
\text { adjacent } \\
\text { industries }\end{array}$ & 18-m buses) & - Battery & $\begin{array}{l}\text { - Fuel cell in } \\
\text { automotive } \\
\text { - } \mathrm{H}_{2} \text { supply } \\
\text { Battery, electric } \\
\text { drives }\end{array}$ & $\begin{array}{l}\text { - Infrastructure } \\
\text { - Battery } \\
\text { - Electric drives }\end{array}$ & $\begin{array}{l}\text { - Infrastructure } \\
\text { - Battery } \\
\text { - Electric drives }\end{array}$ & \\
\hline $\begin{array}{l}\text { Data on all po } \\
\text { - Data on hy } \\
\text { fleets with } \\
\text { - Data on ele } \\
\text { componen } \\
\text { remaining } \\
\text { - Data on hy }\end{array}$ & $\begin{array}{l}\text { wertrains to be treate } \\
\text { drogen fuel cell buse } \\
\text { a time frame of a few } \\
\text { ctric buses (opportur } \\
\text { ts, diesel serial hybr } \\
\text { parts as no informatio } \\
\text { brids are based on a }\end{array}$ & $\begin{array}{l}\text { ed with appropriate } \\
\text { s are based on real-I } \\
\text { years } \\
\text { nity and overnight e-bu } \\
\text { id Clean Team data } f \\
\text { on from actual operatic } \\
\text { few years of experie }\end{array}$ & $\begin{array}{l}\text { caution as } \\
\text { life operations (12-n } \\
\text { uses) are based on C } \\
\text { for other componen } \\
\text { on of } 12-m \text { or } 18-m \text { bu } \\
\text { nce only despite larg }\end{array}$ & $\begin{array}{l}\text { m or 18-m buses) in sm } \\
\text { Ilean Team data for th } \\
\text { uses was available } \\
\text { ge number of buses }\end{array}$ & $\begin{array}{l}\text { nall-scale } \\
\text { te core } \\
\text { tes for the }\end{array}$ & \\
\hline
\end{tabular}

Figure 11. Status of different low emission bus drivetrain technologies in Europe (Source: 'Urban buses: alternative powertrains for Europe') 


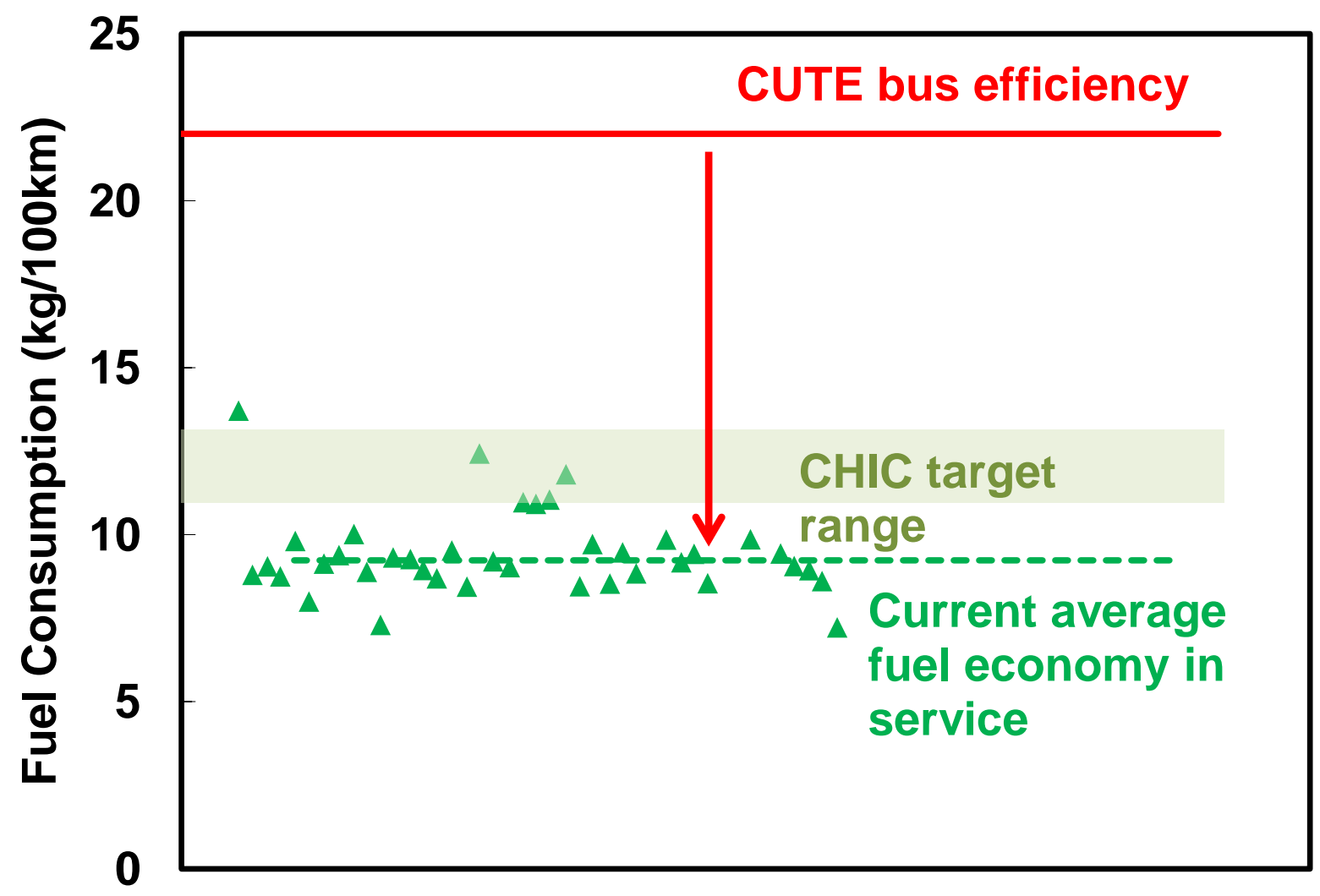

Figure 12. Average fuel consumption of FCEBs in London (Source: Transport of London) 


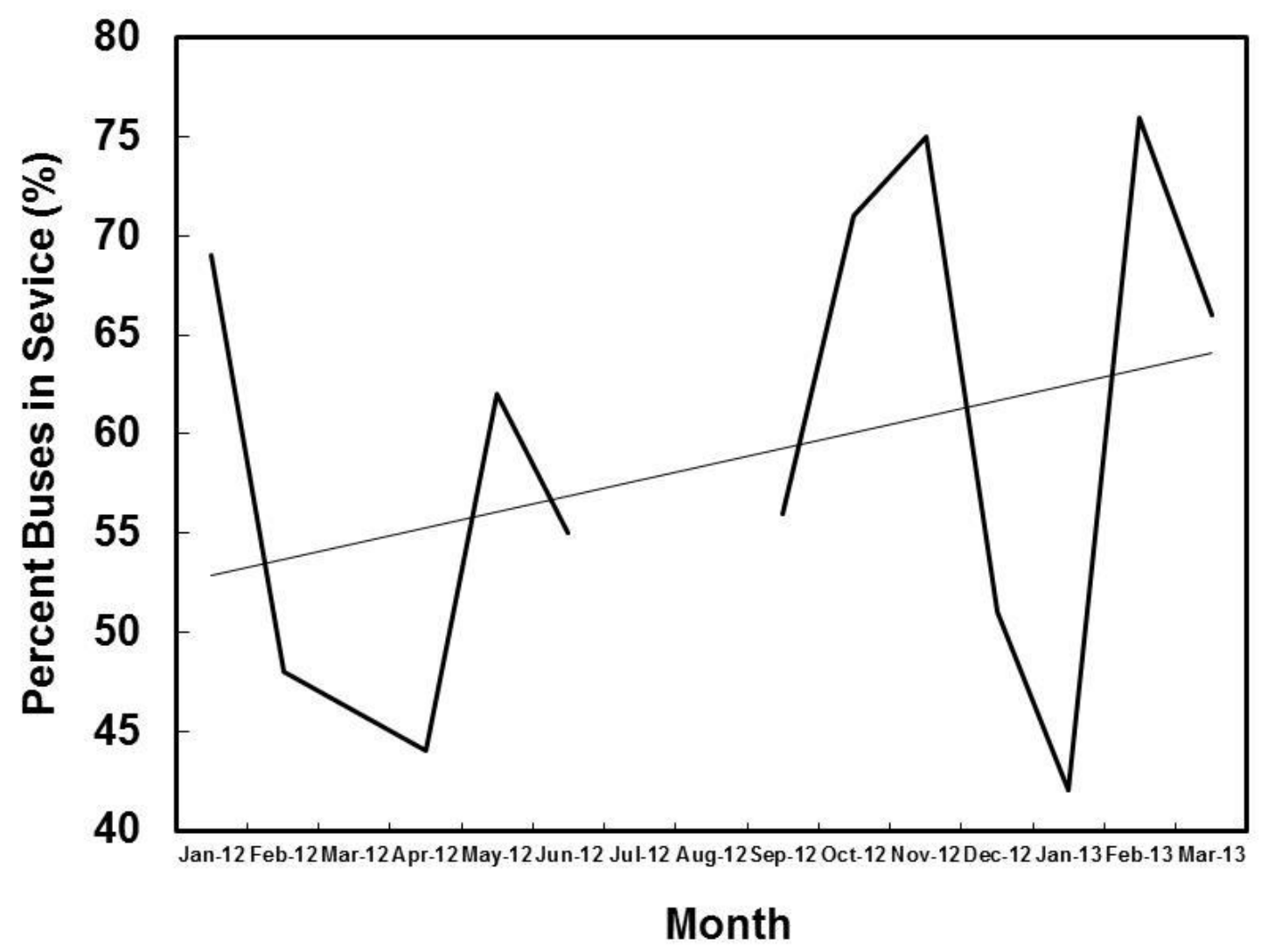

Figure 13. Availability of London FCEBs January 2012-March 2013 (Source: Transport of London). Note: no data between June-September 2012, as the buses were withdrawn from service during the London Olympics period. 


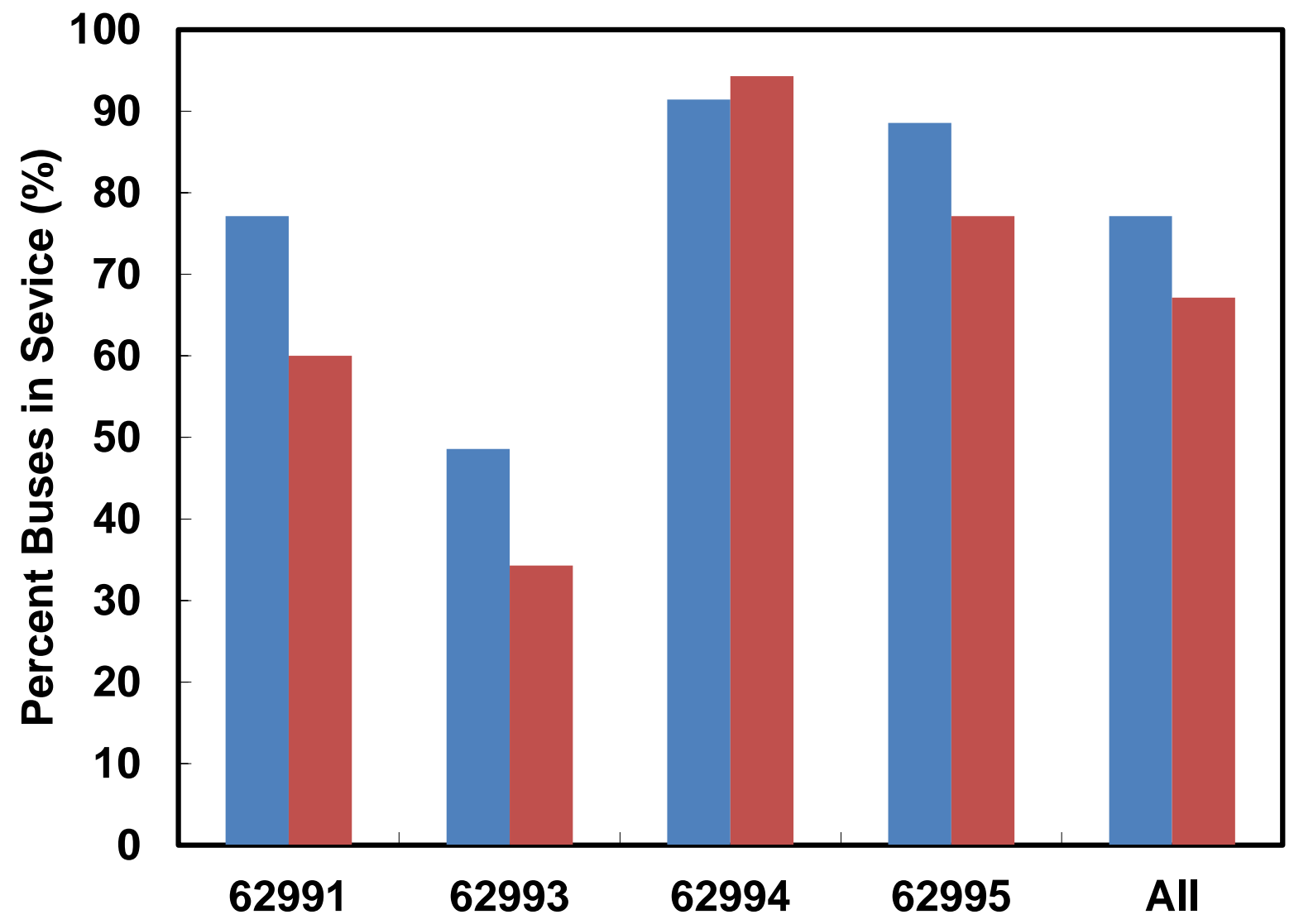

Figure 14. Individual bus availability data for the London FCEB deployment, February March 2013 (Source: Transport of London) 


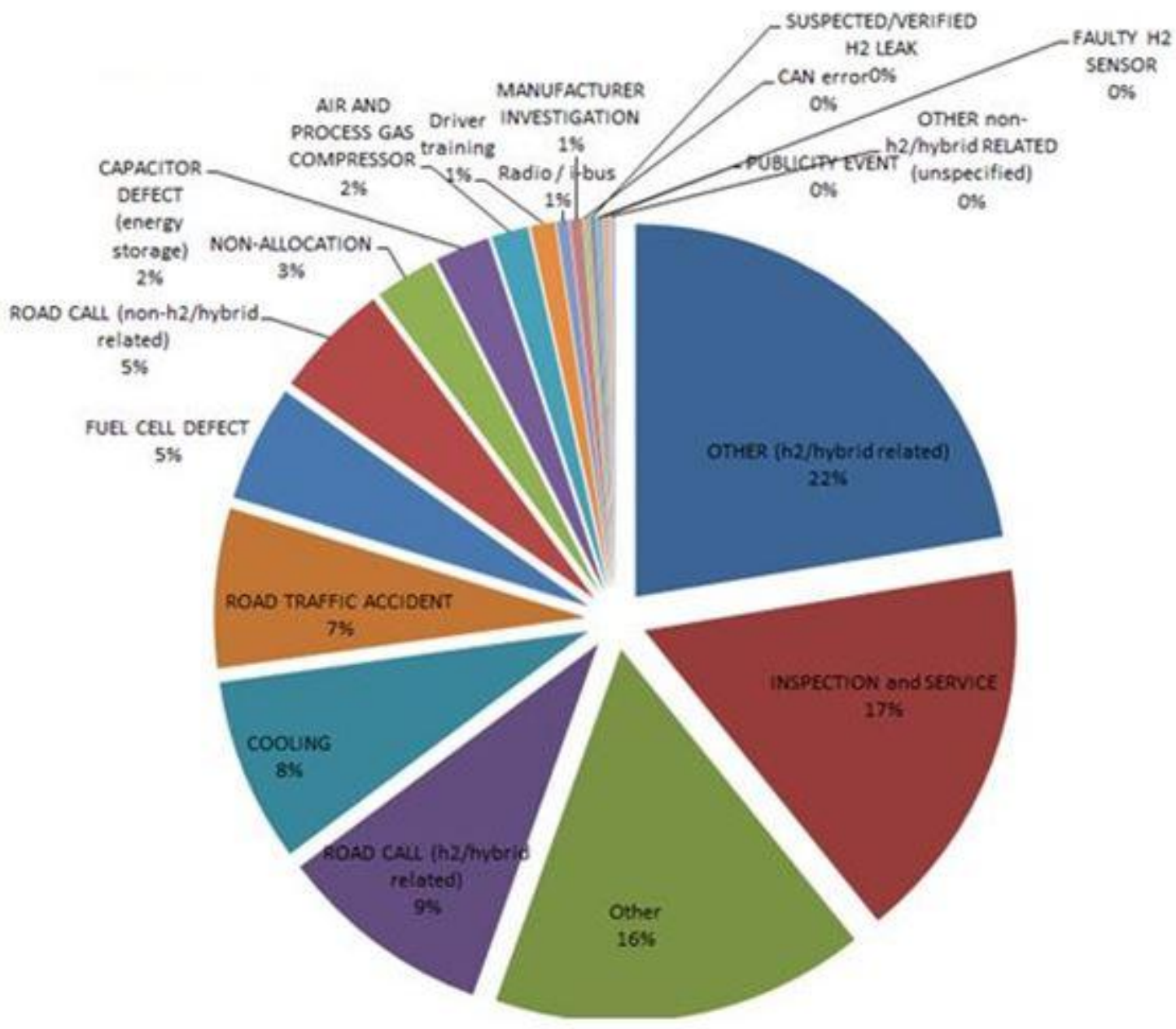

Figure 15. Reasons for downtime in London FCEB deployment (Source: Transport of London) 


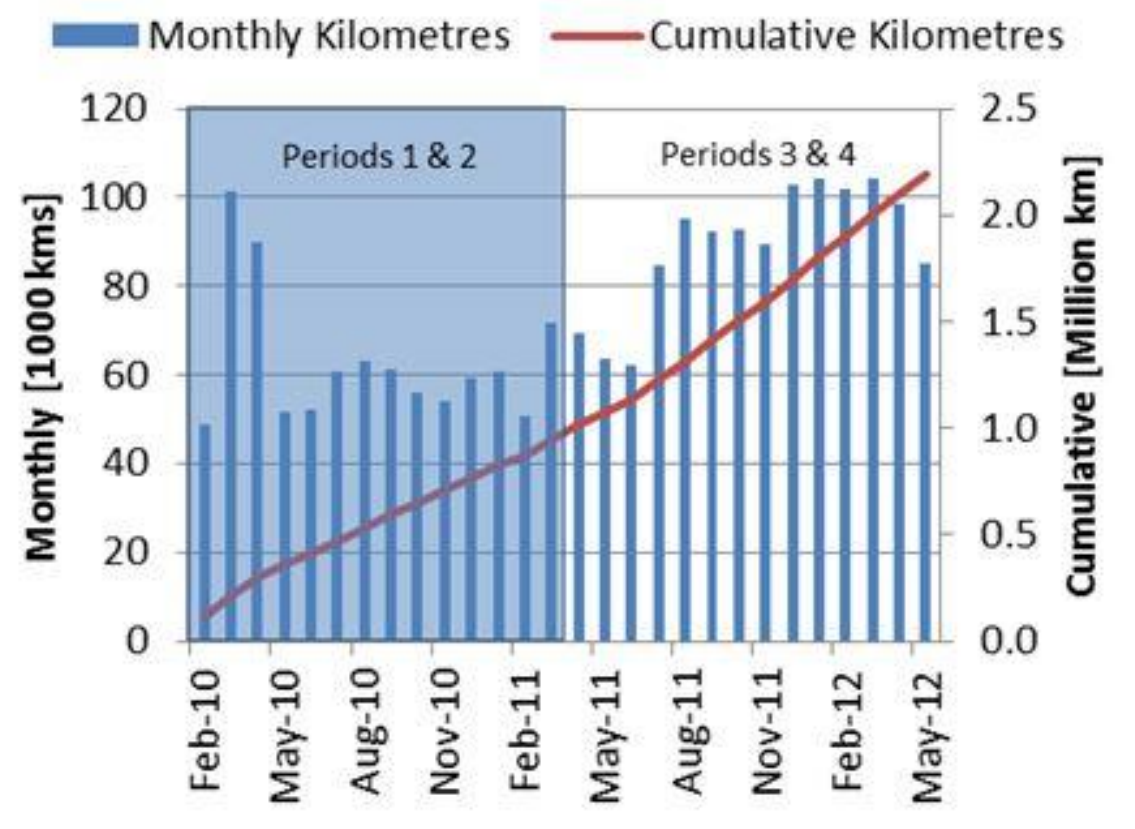

Figure 16 Accumulated distance of complete fleet from February 2010 to May 2012 


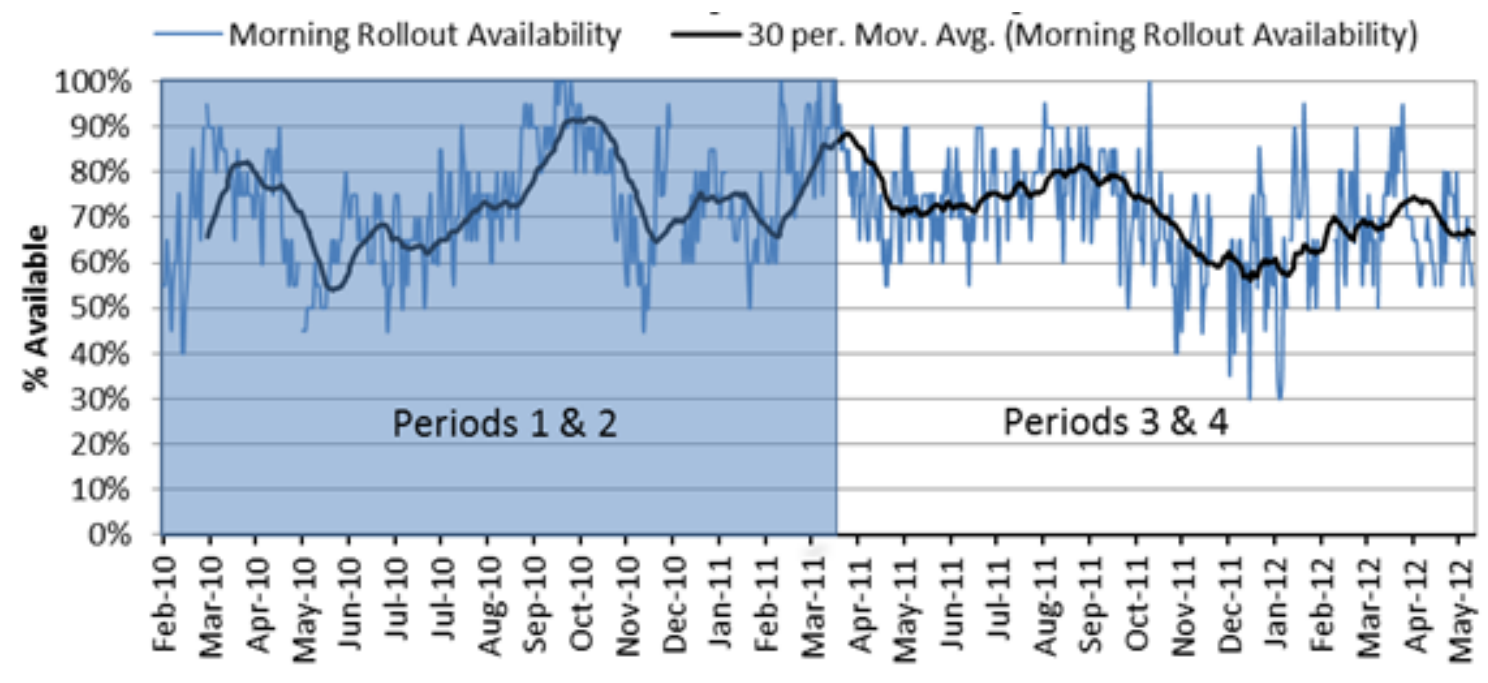

Figure 17. Fleet availability from February 2010 to May 2012 


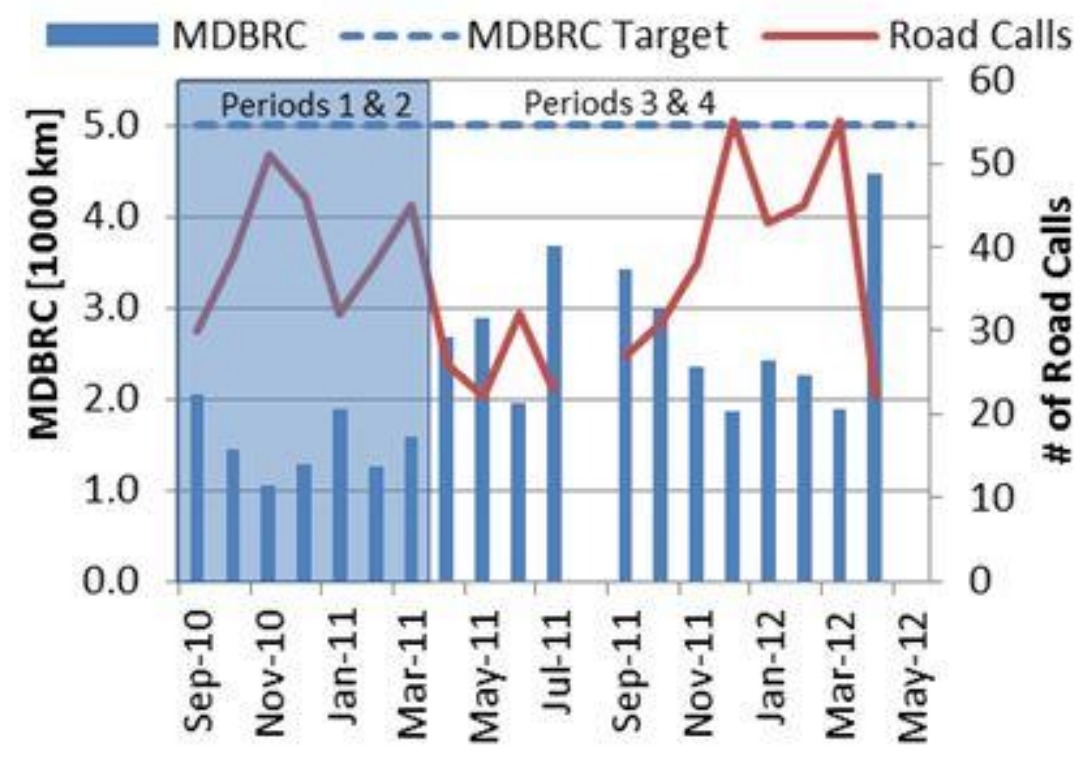

Figure 18: Mean distance between road calls 


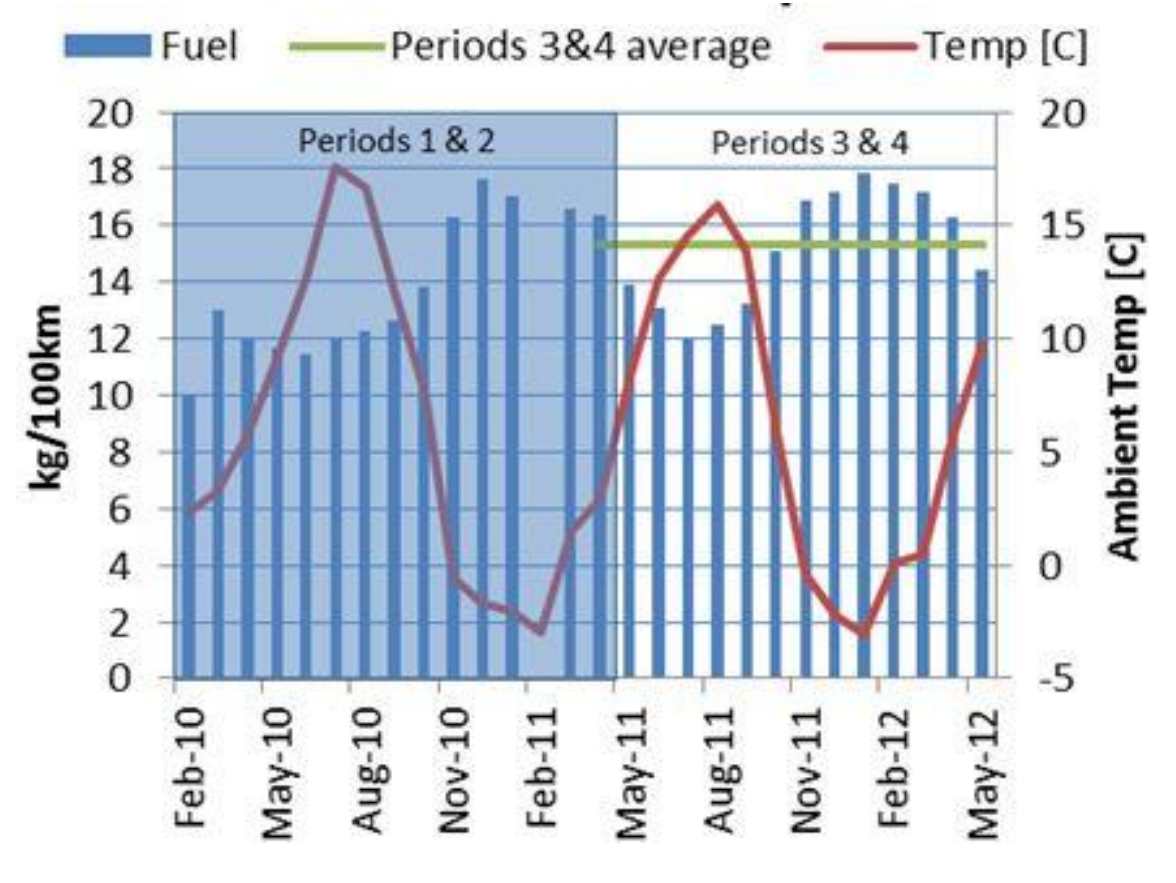

Figure 19. Average monthly fuel economy 


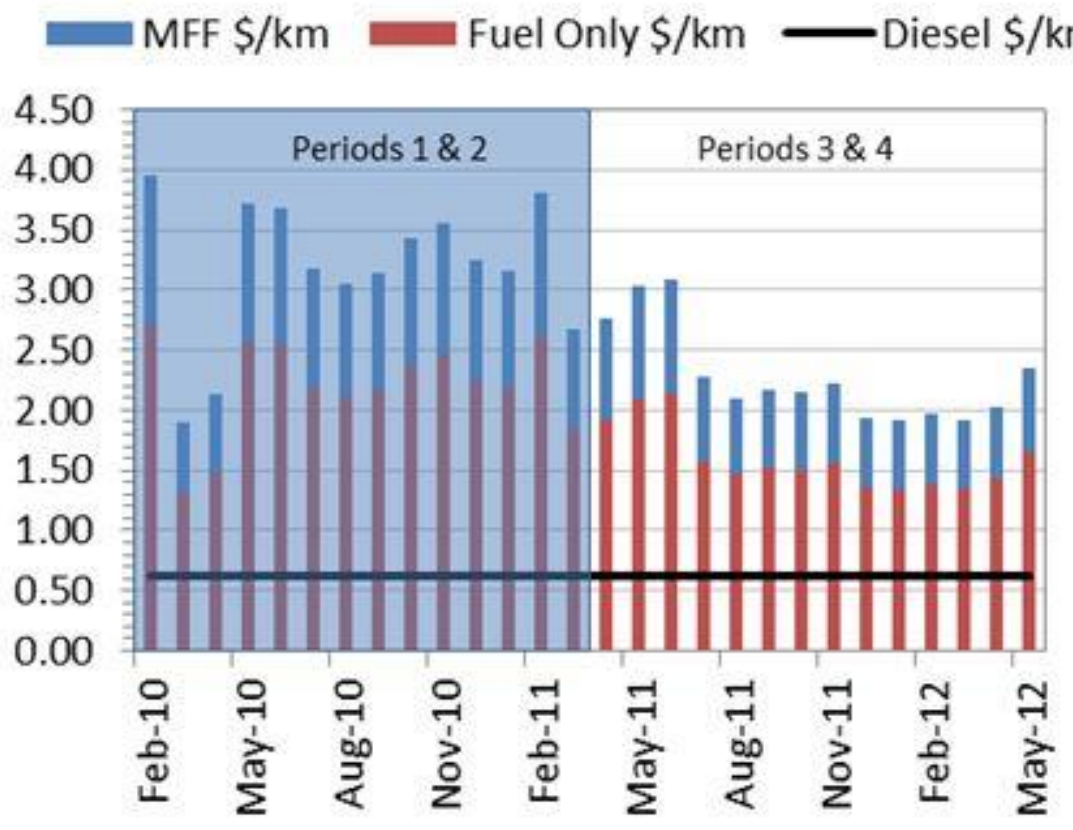

Figure 20. Total fuel cost per $\mathrm{km}$ including monthly facility fee and monthly minimum consumption 


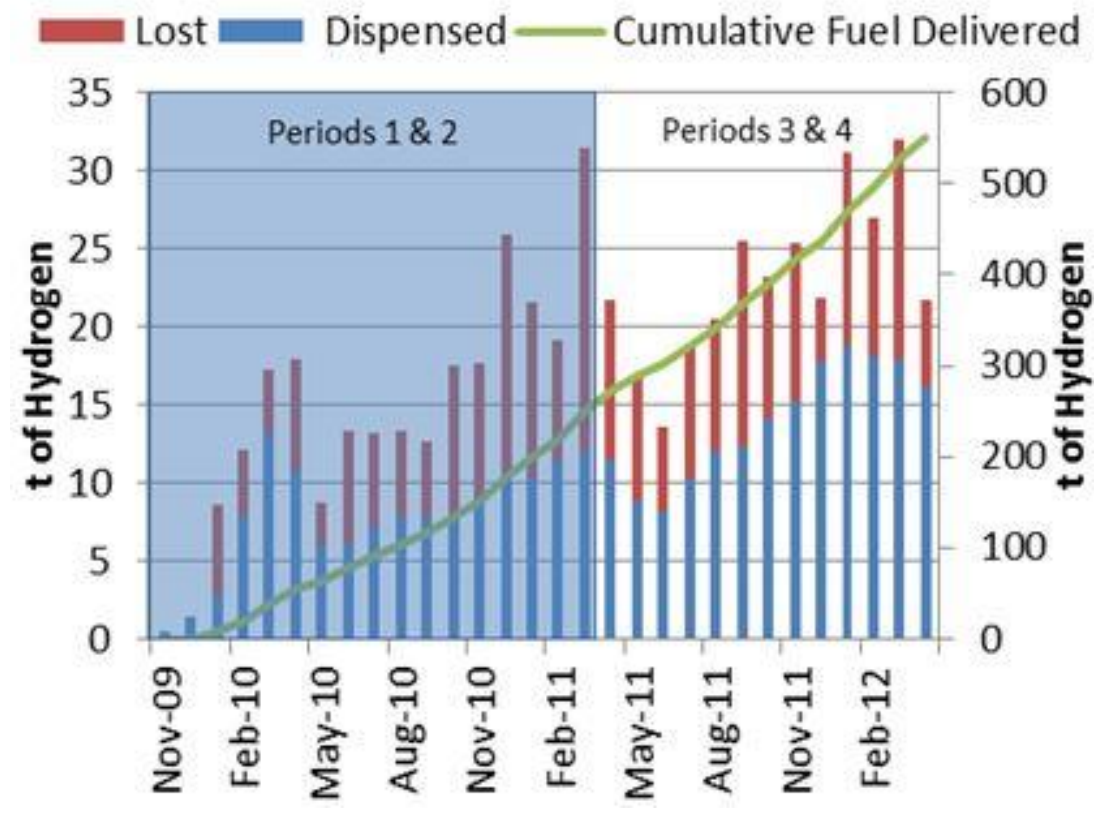

Figure 21. Total fuel delivered including cumulative and the split between dispensed fuel and lost fuel. 
Monthly _- Project Ave —Time to Dispense $50 \mathrm{~kg}$

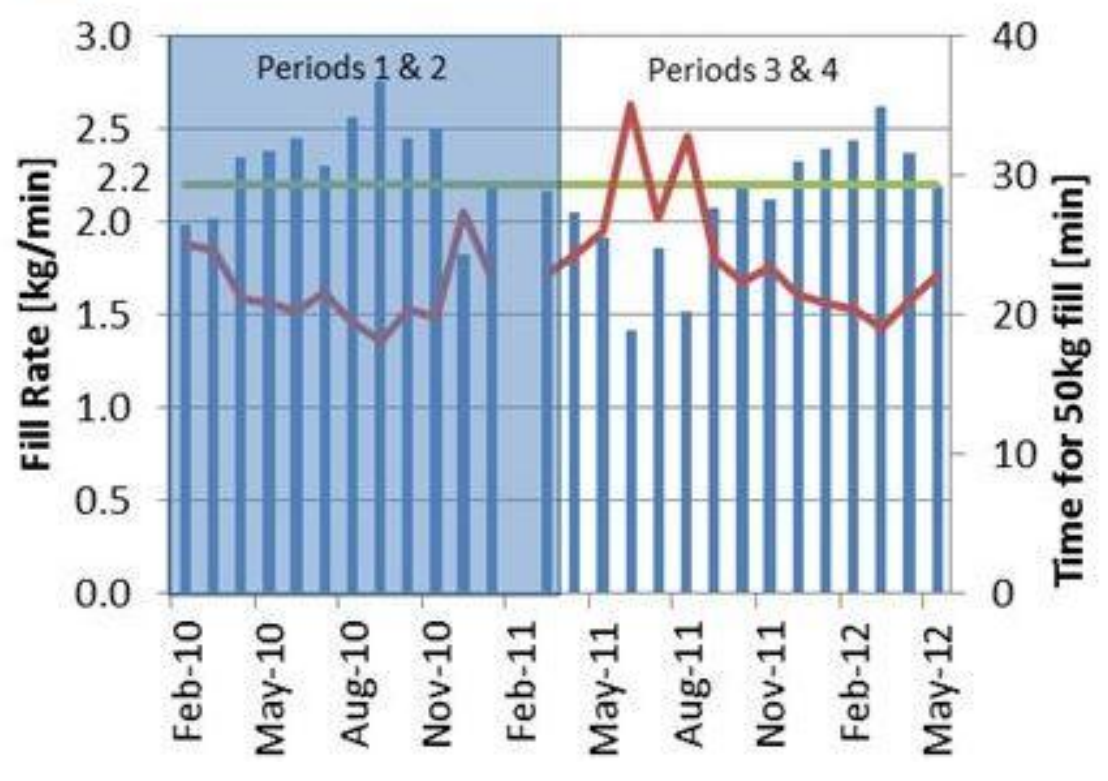

Figure 22. Average fuelling rate. The project average and time to dispense $50 \mathrm{~kg}$ are also shown 

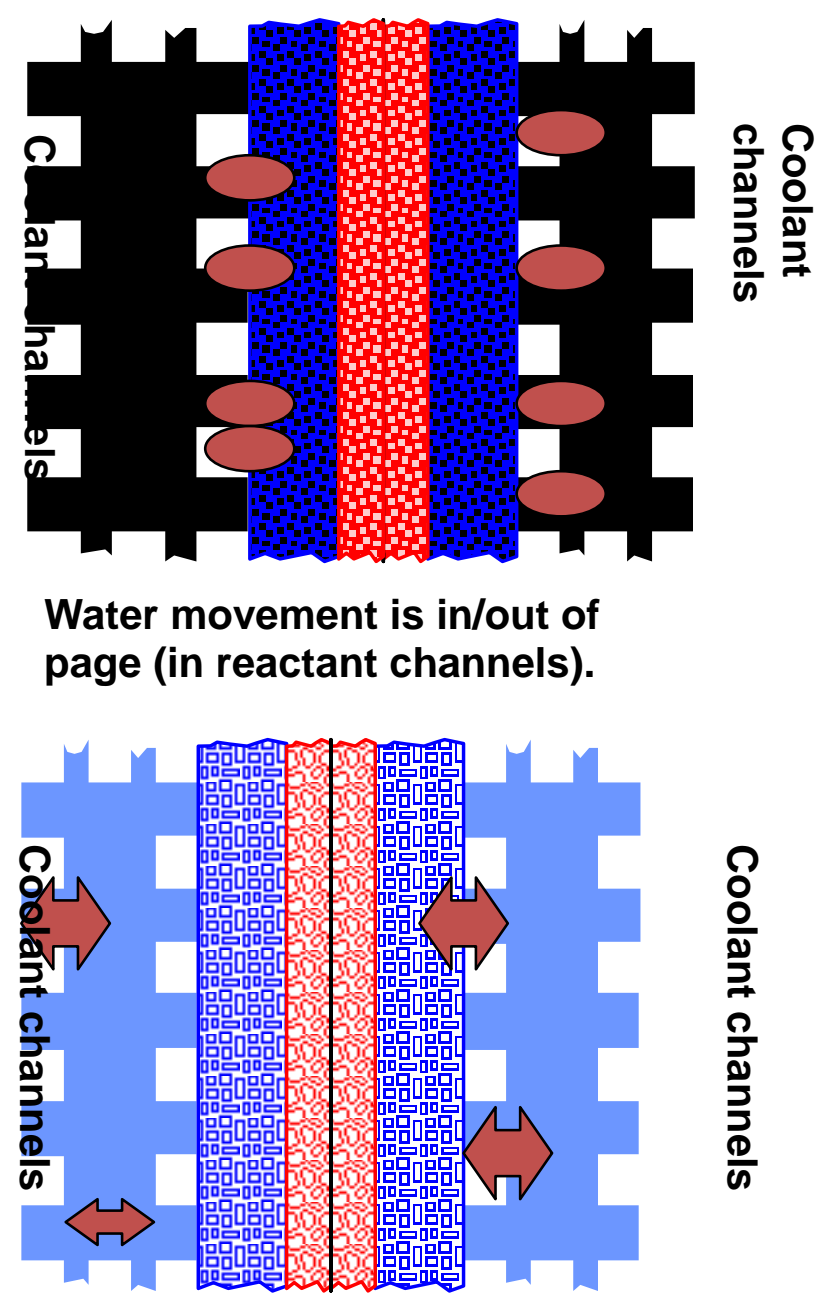

\section{Water movement depicted by} arrows (through plates).

Figure 23. Schematic comparing solid plate water management strategy (top image) and ClearEdge Power's porous plate water management strategy. 


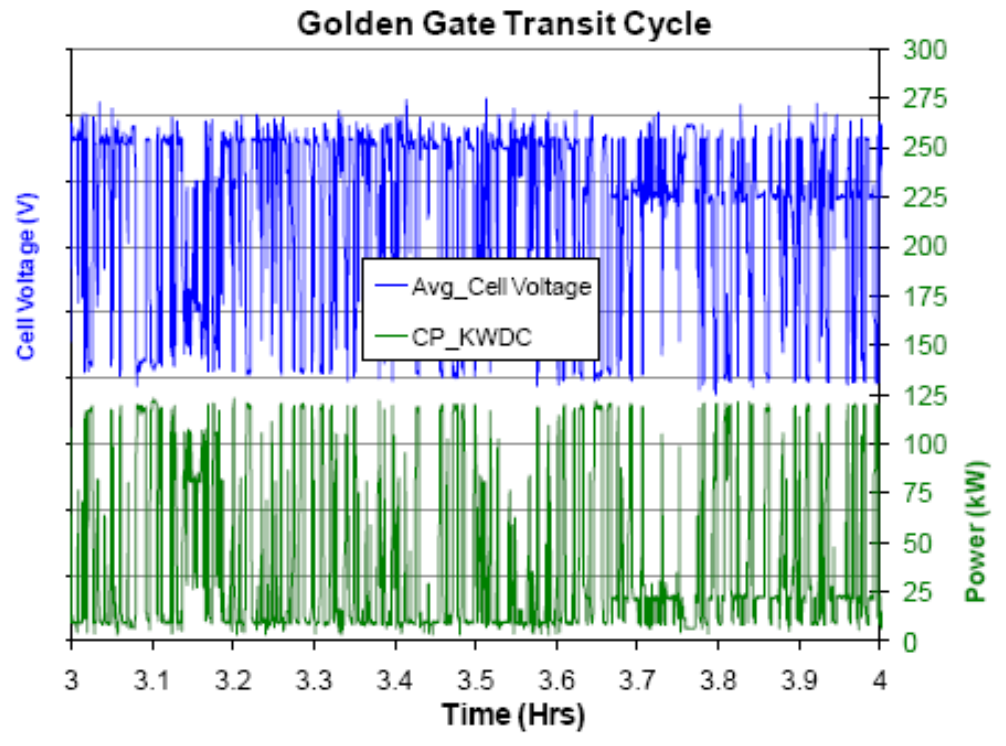

Figure 24. Typical load-voltage profile for ClearEdge Power bus fleet. 


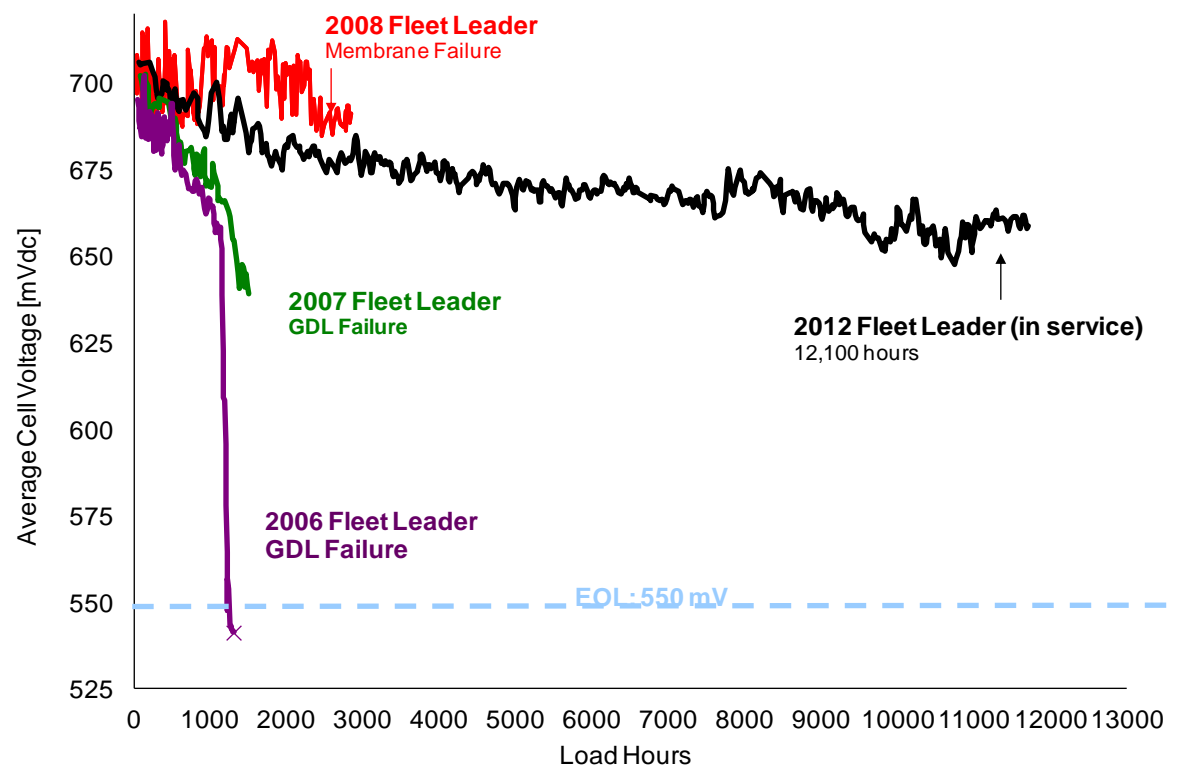

Figure 25. ClearEdge Power fleet data. 


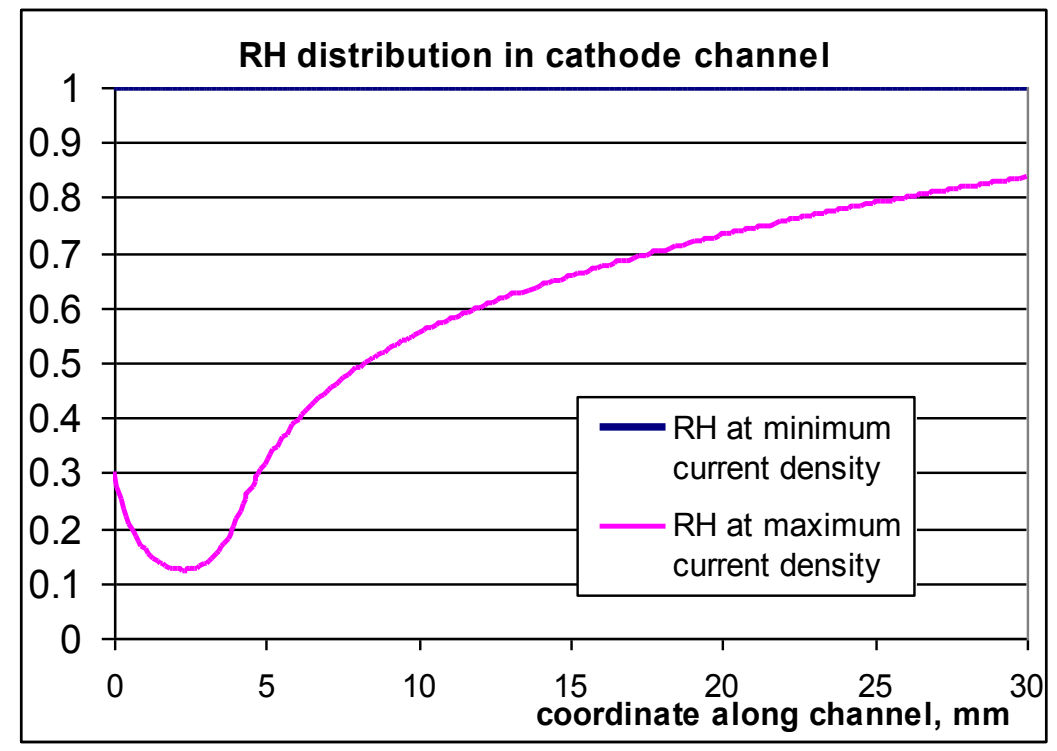

Figure 26. Model results showing relative humidity of gases in cathode channel as function of distance from air inlet. The RH at minimum current density is unity. 


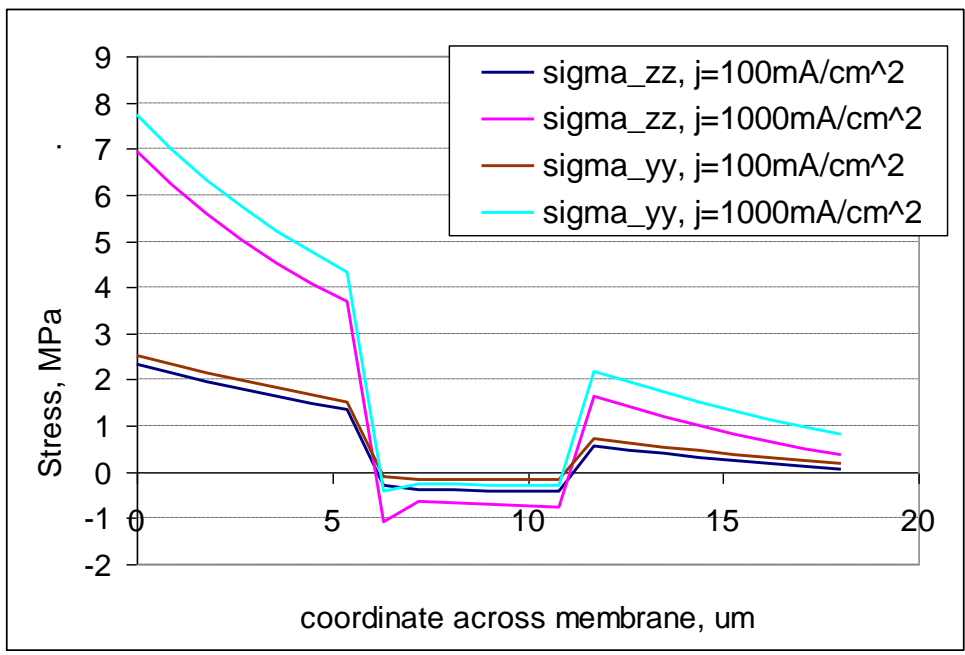

Figure 27. In-plane elastic stress profiles in the membrane near air inlet $(y=0.5 \mathrm{~cm})$ at the middle of the channel $\left(x=L_{c h} / 2\right)$ for two current densities $\left(j=100 \mathrm{~mA} / \mathrm{cm}^{2}\right.$ and $j=1000$ $\mathrm{mA} / \mathrm{cm}^{2}$ ). 


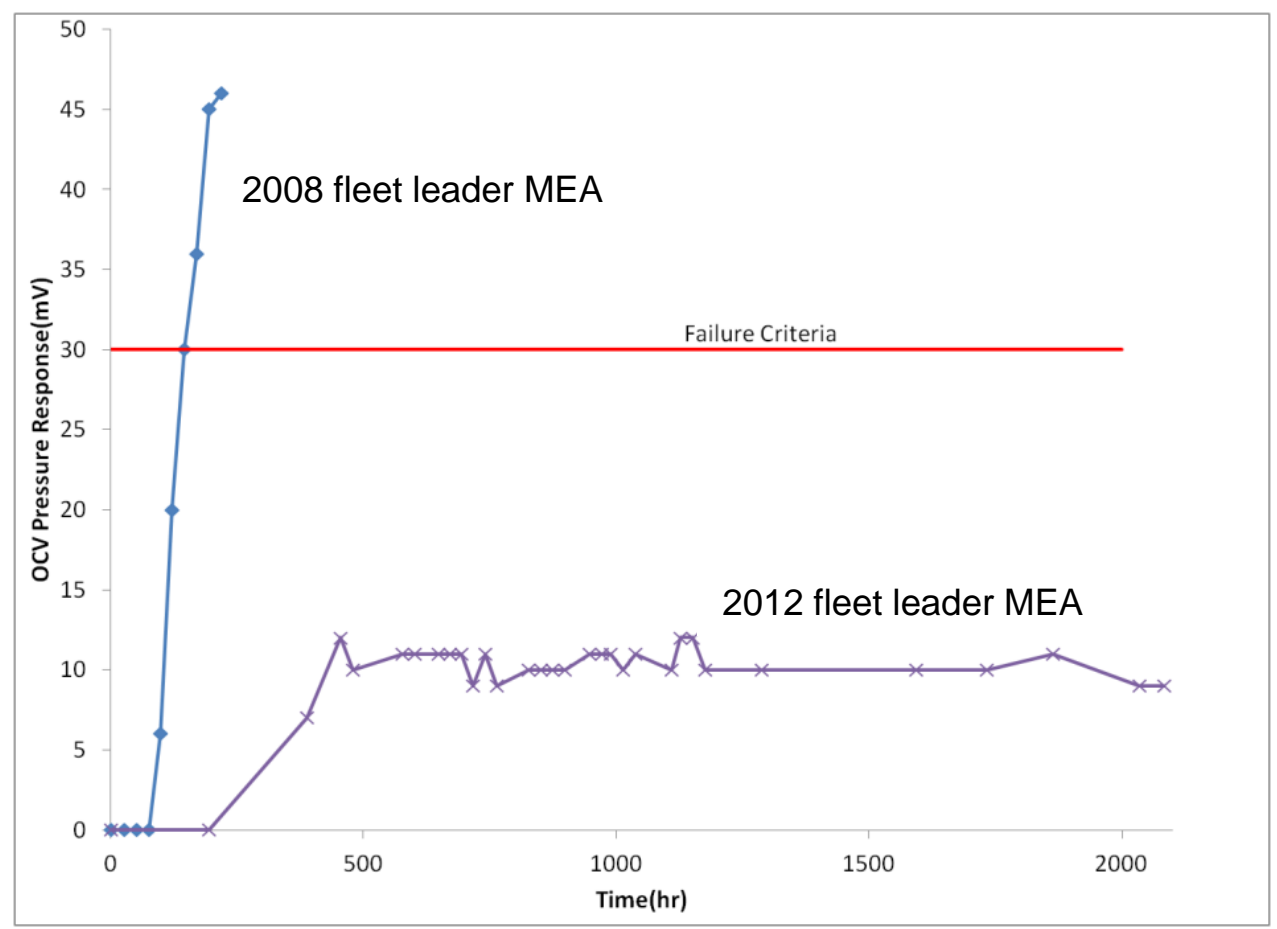

Figure 28. Comparison of 2012 and 2008 fleet leader MEA in membrane mechanicalchemical AST. 


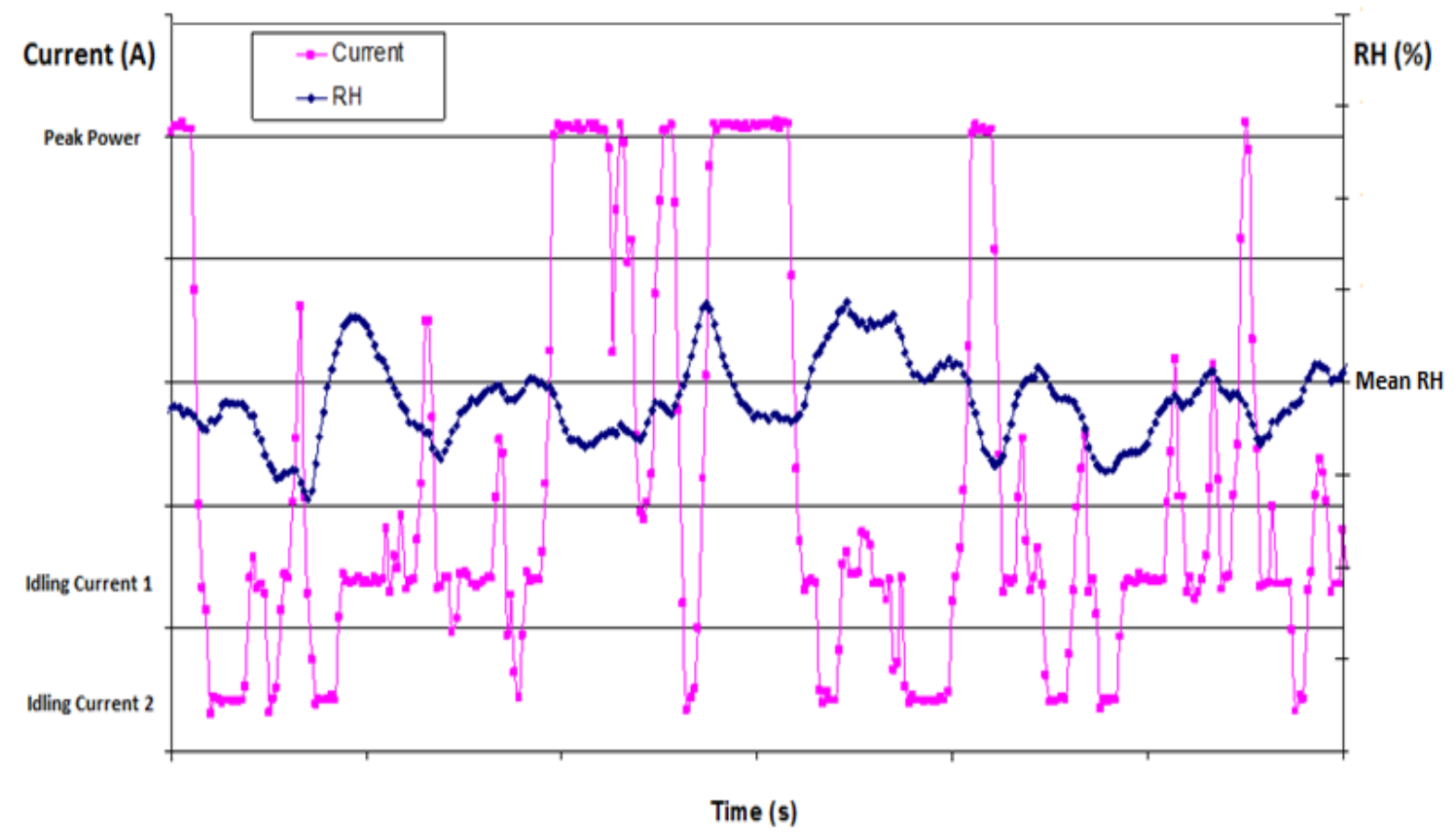

Figure 29. Current profile and corresponding humidity profile of the Whistler buses. 


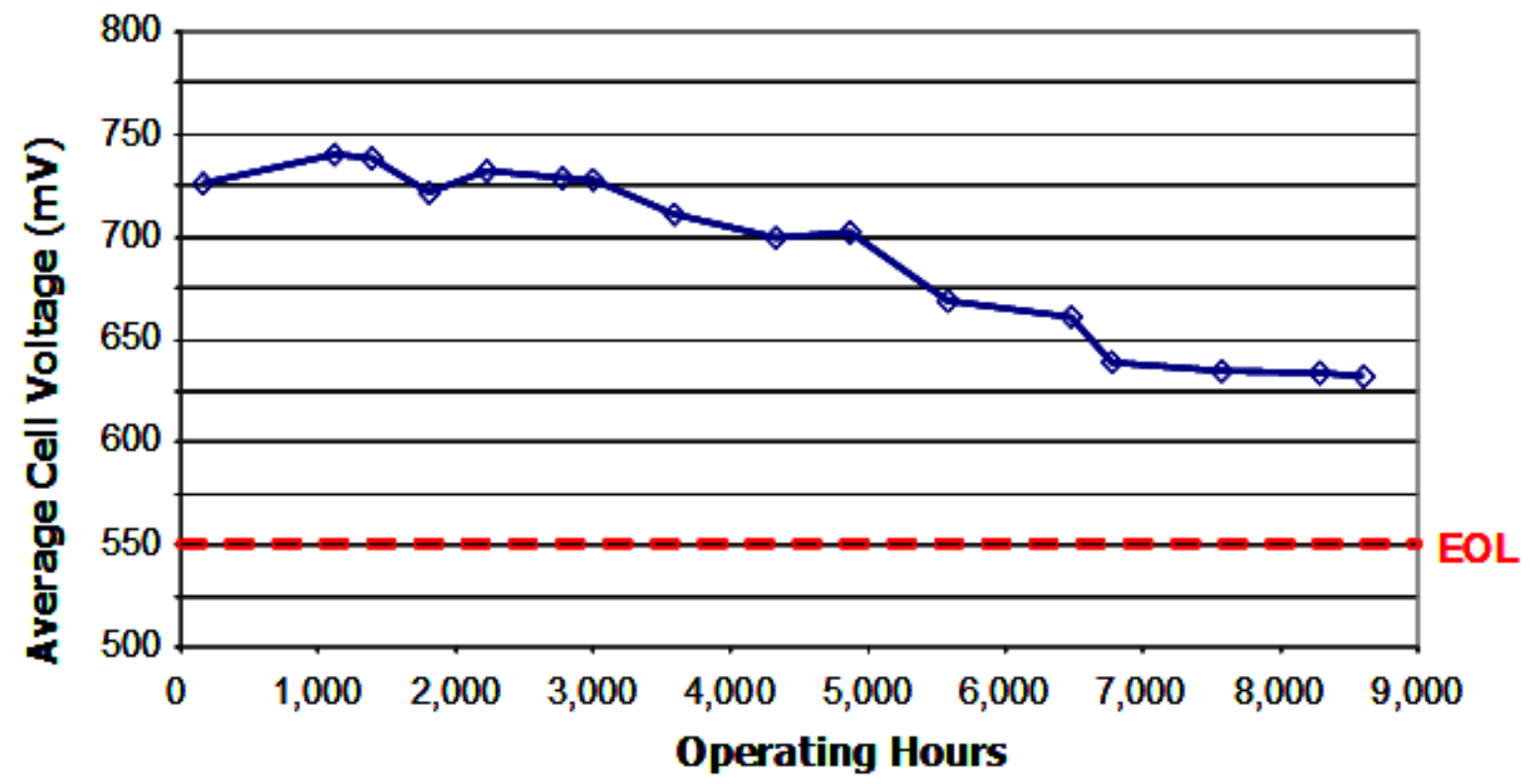

Figure 30. Fuel cell stack performance at $250 \mathrm{~A}$ after $\sim 9000$ hours of operation in Whistler. 


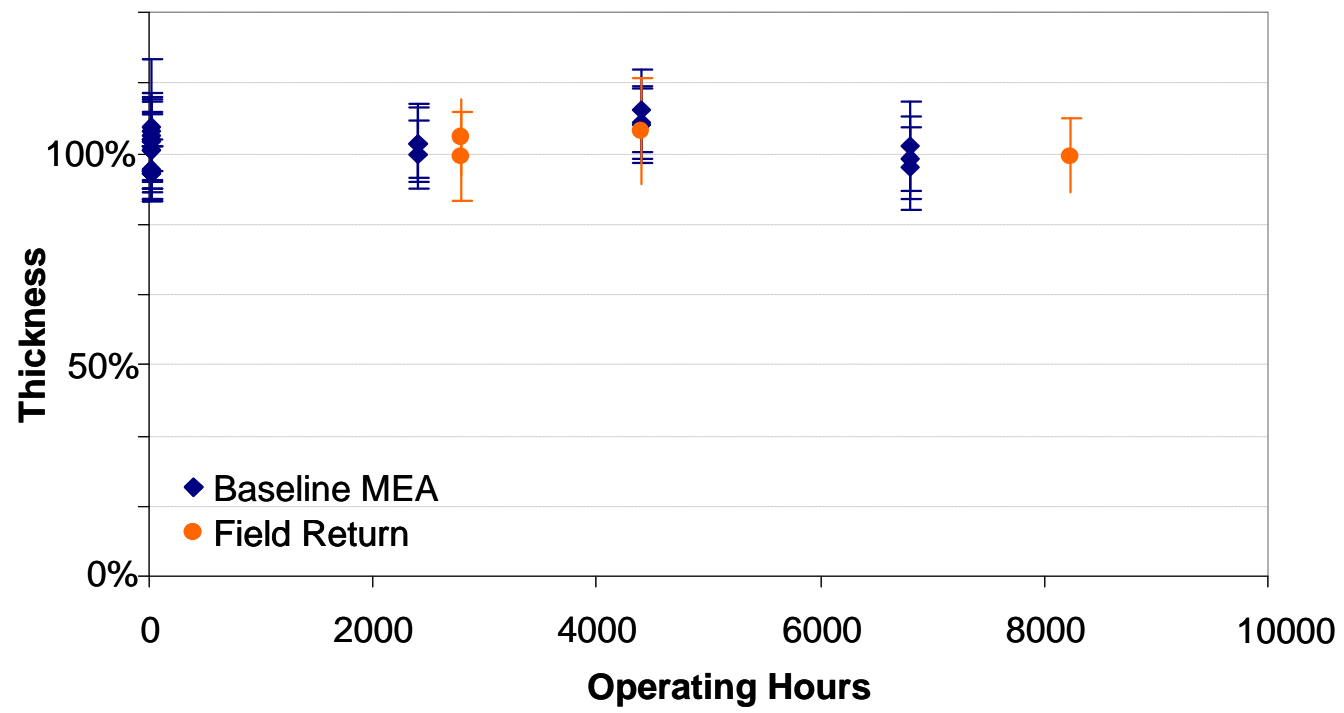

Figure 31. Membrane thickness variation with operating hours of MEAs from the Whistler buses and stacks with the same MEA (baseline) operated in the laboratory. 

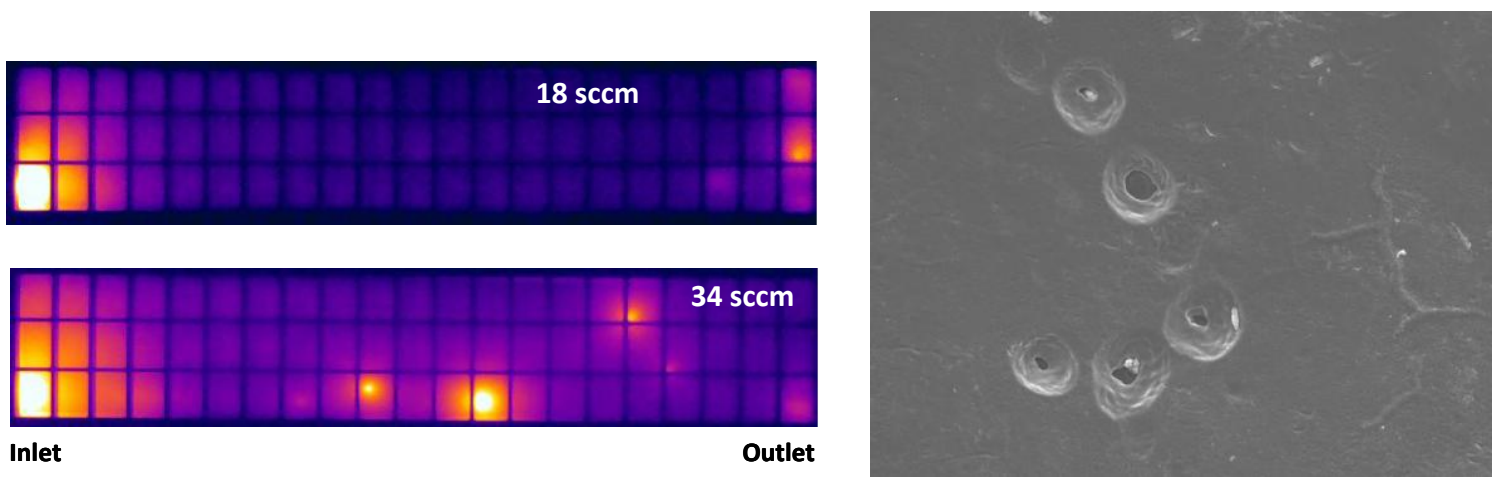

Figure 32. Typical IR image and pinhole in the membrane of an MEA that was operated in the Whistler fuel cell stack. 


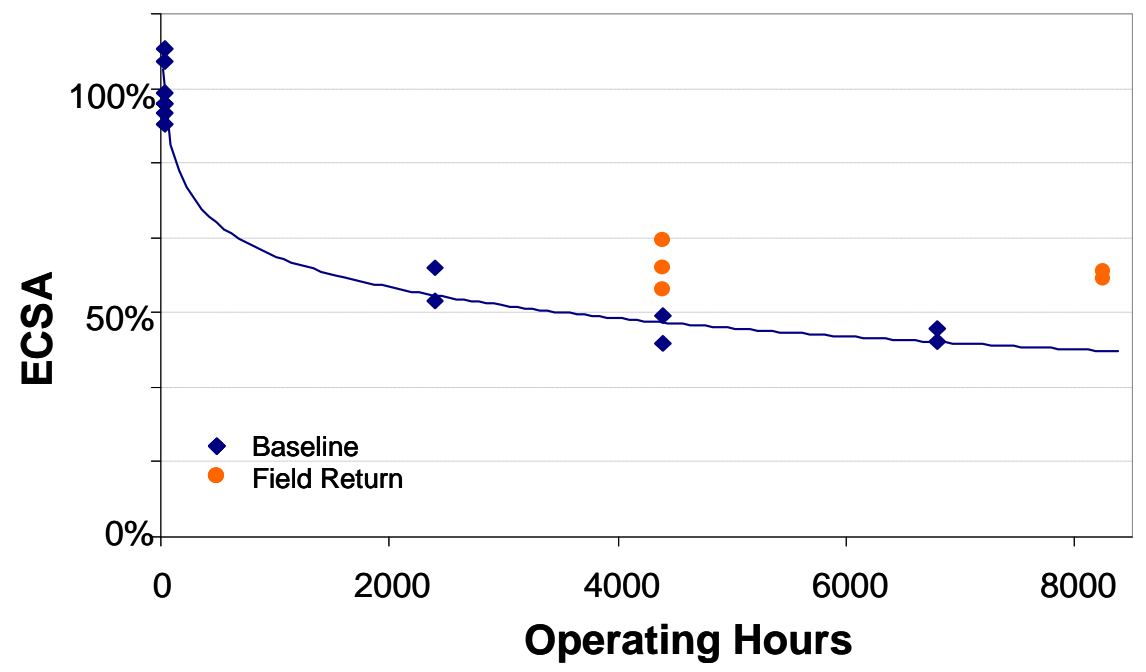

Figure 33. Cathode ECSA changes with operating hours for MEAs from the Whistler buses and stacks with the same MEA (baseline) operated in the laboratory. 


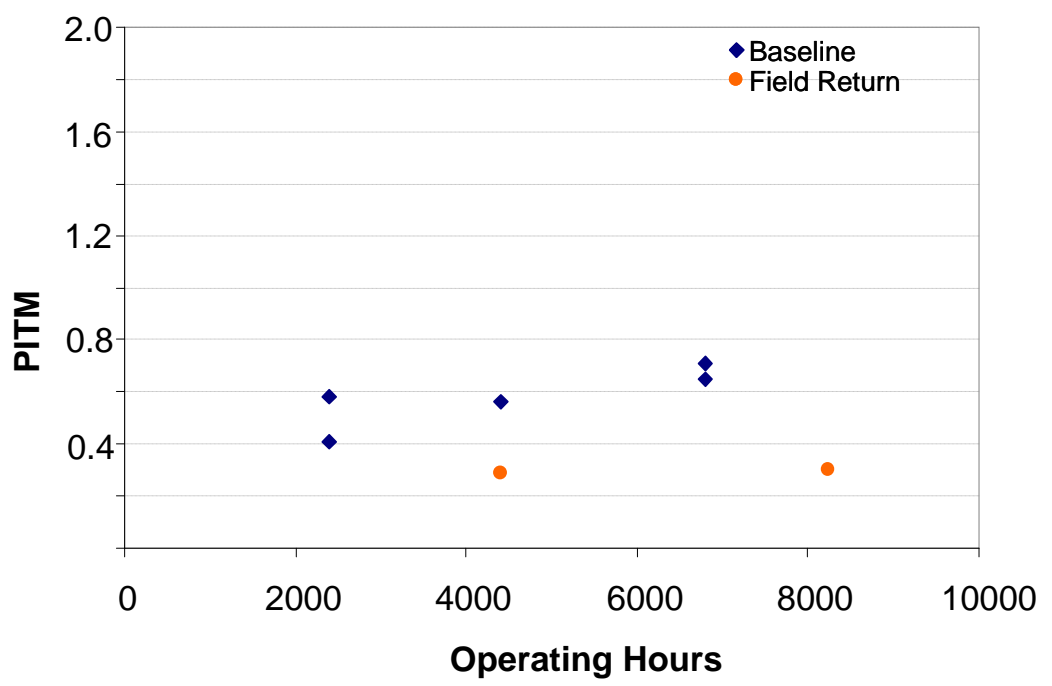

Figure 34. Platinum migrated into the membrane after different operating hours of MEAs from the Whistler buses and laboratory stacks with the same MEA (baseline). 


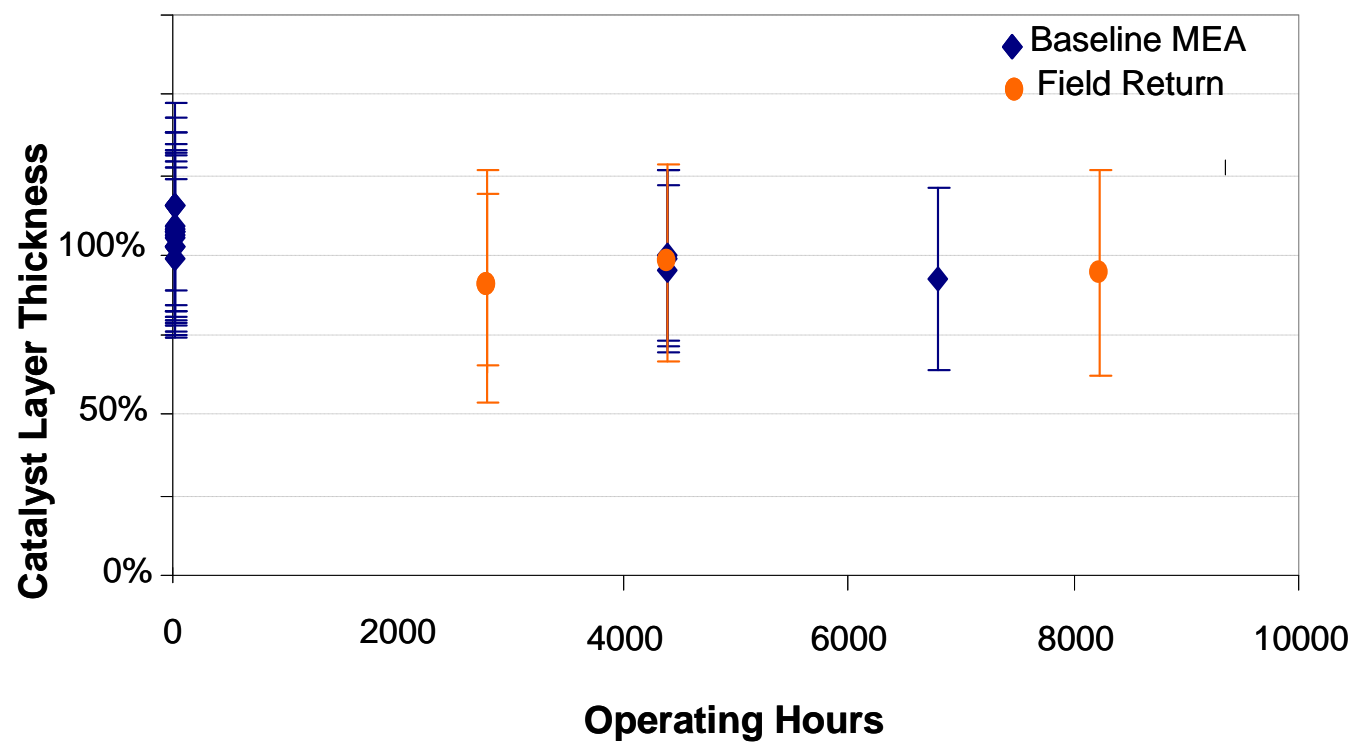

Figure 35. Catalyst layer thickness changes with operating hours of MEAs from the Whistler buses and laboratory stacks with the same MEA (baseline). 


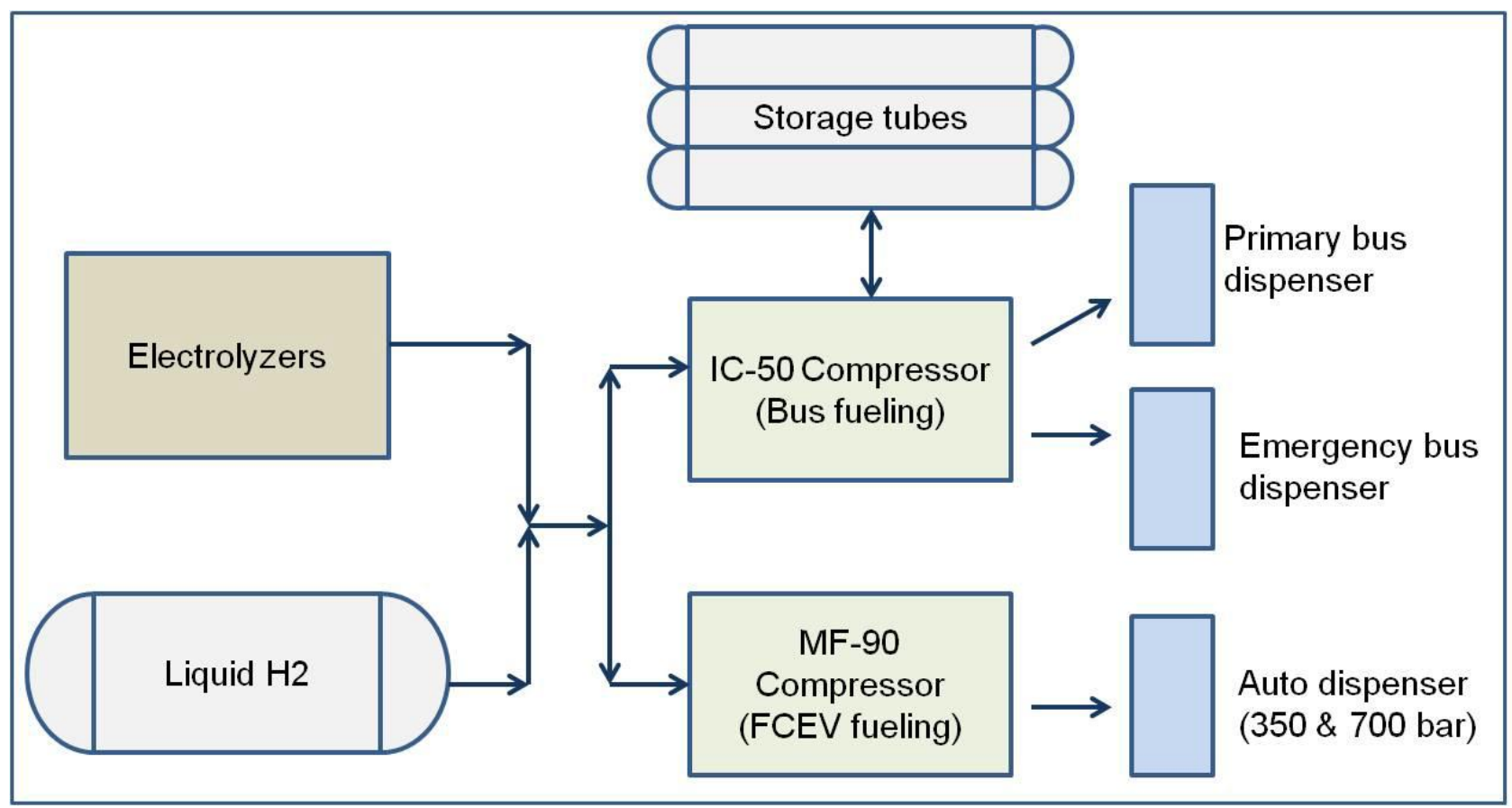

Figure 36. Block diagram of the Emeryville station 


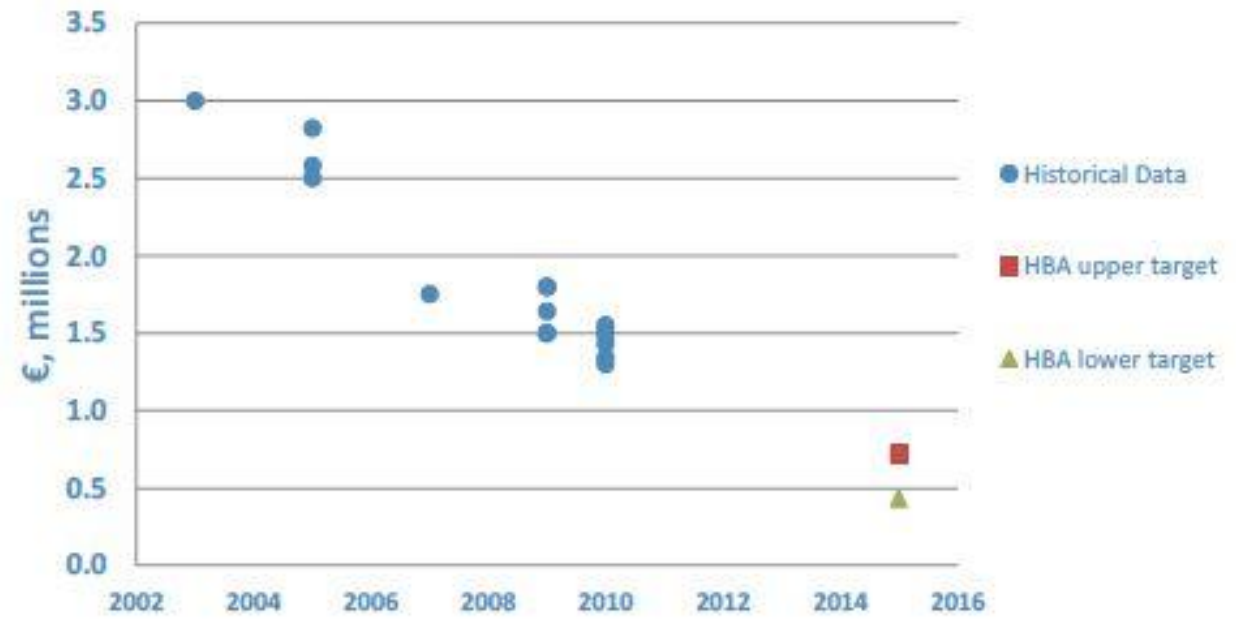

Figure 37. Historical FCEB capital costs, with HBA targets 


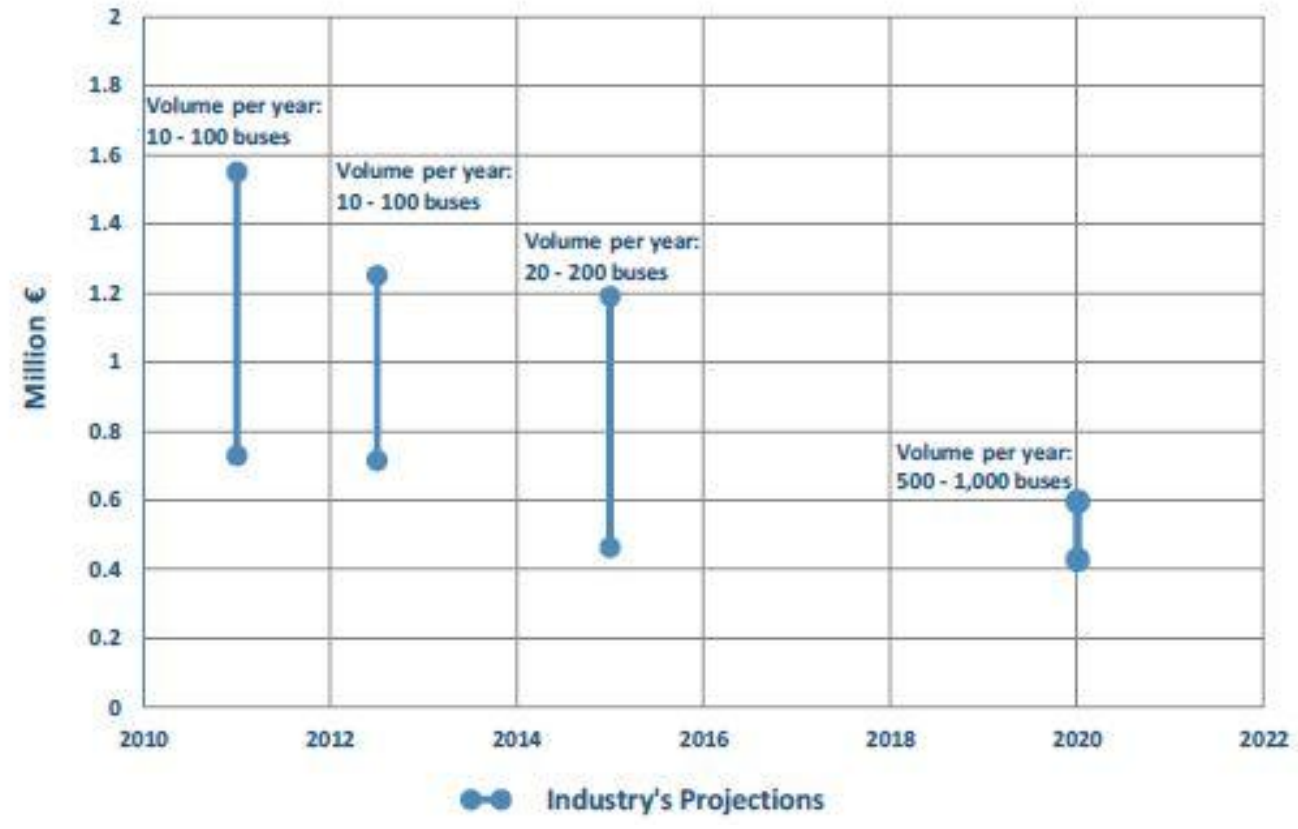

Figure 38. FCEB capital cost industry projections (Source: Nexthylights) 


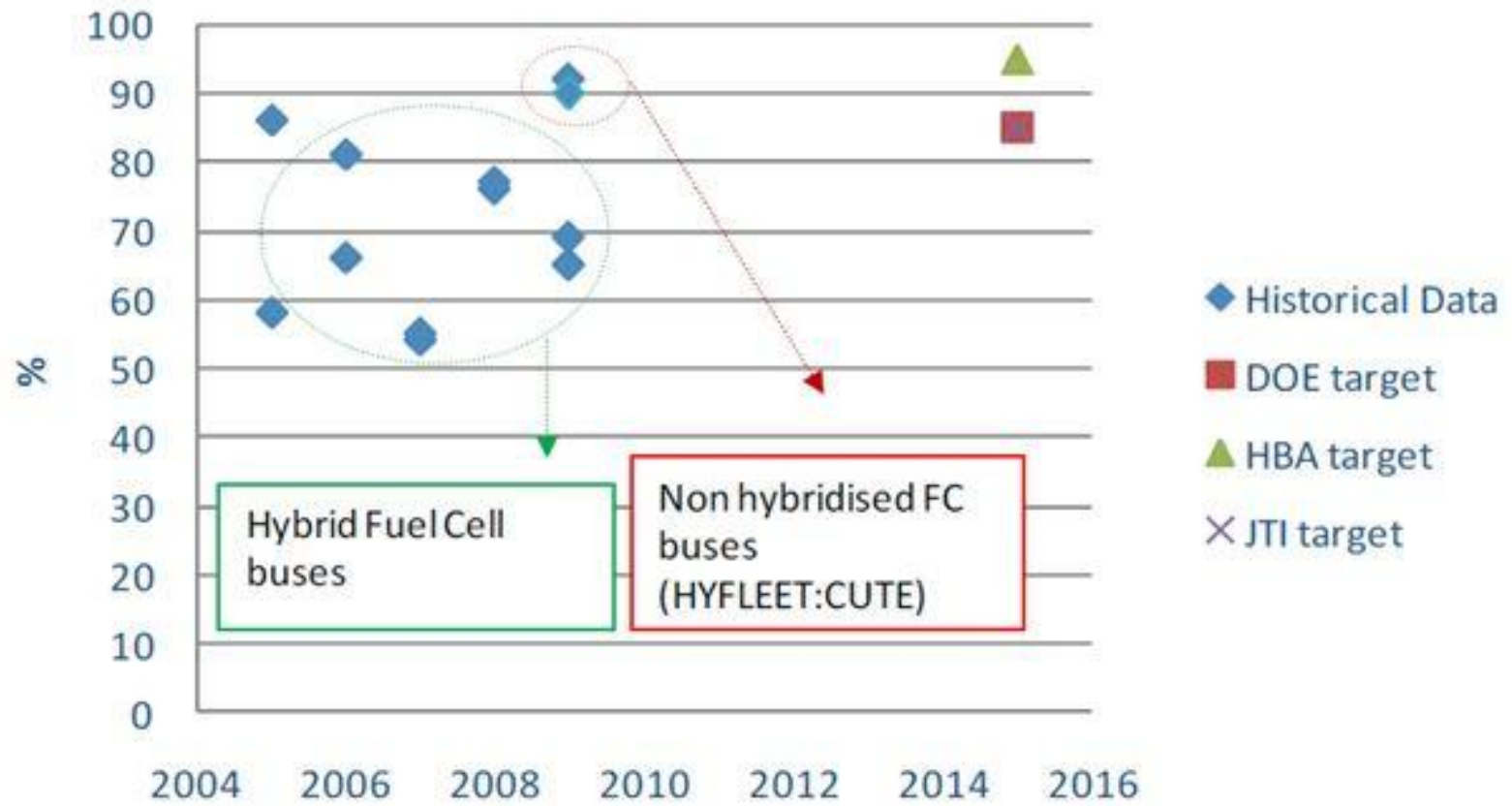

Figure 39. Current and future expected FCEB availability (Source: Nexthylights) 


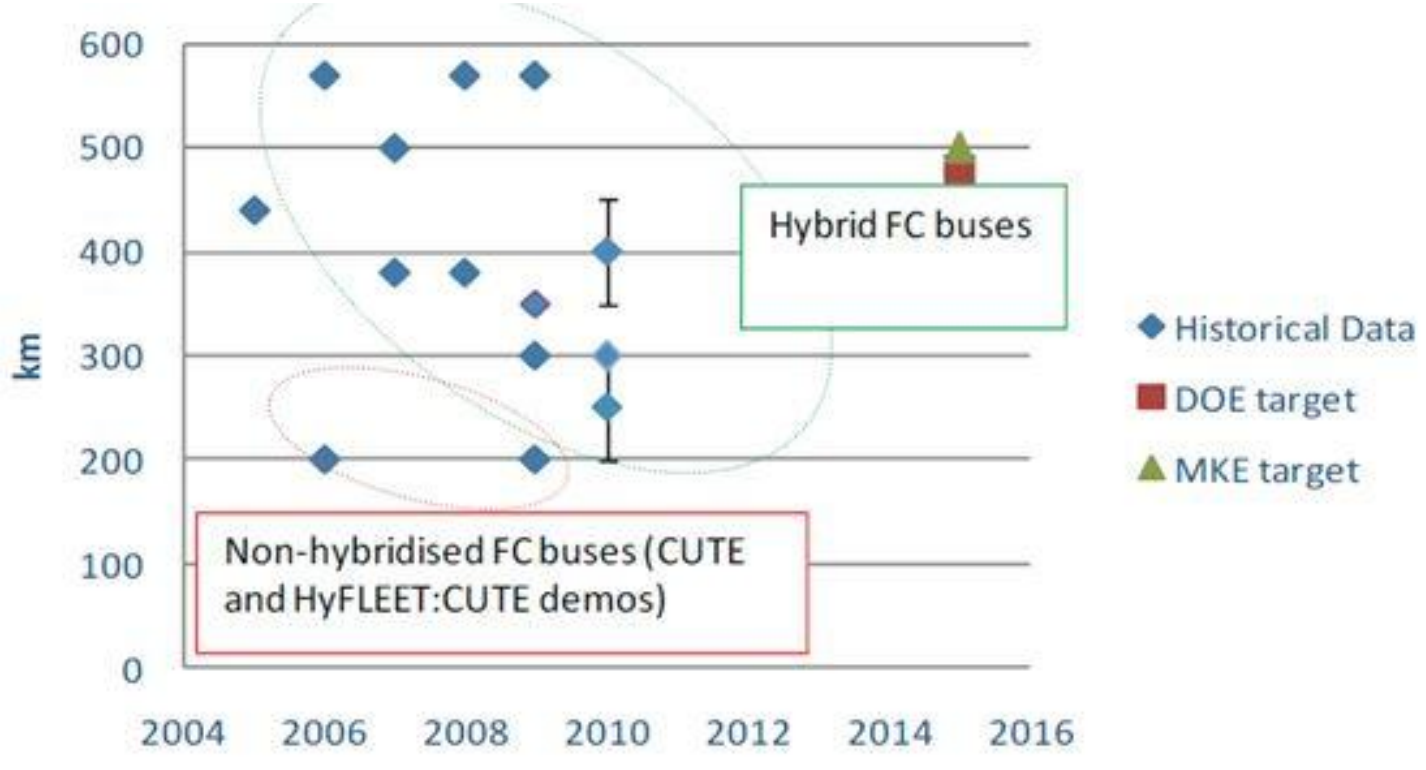

Figure 40. Current and future expected FCEB range (Source: Nexthylights) 


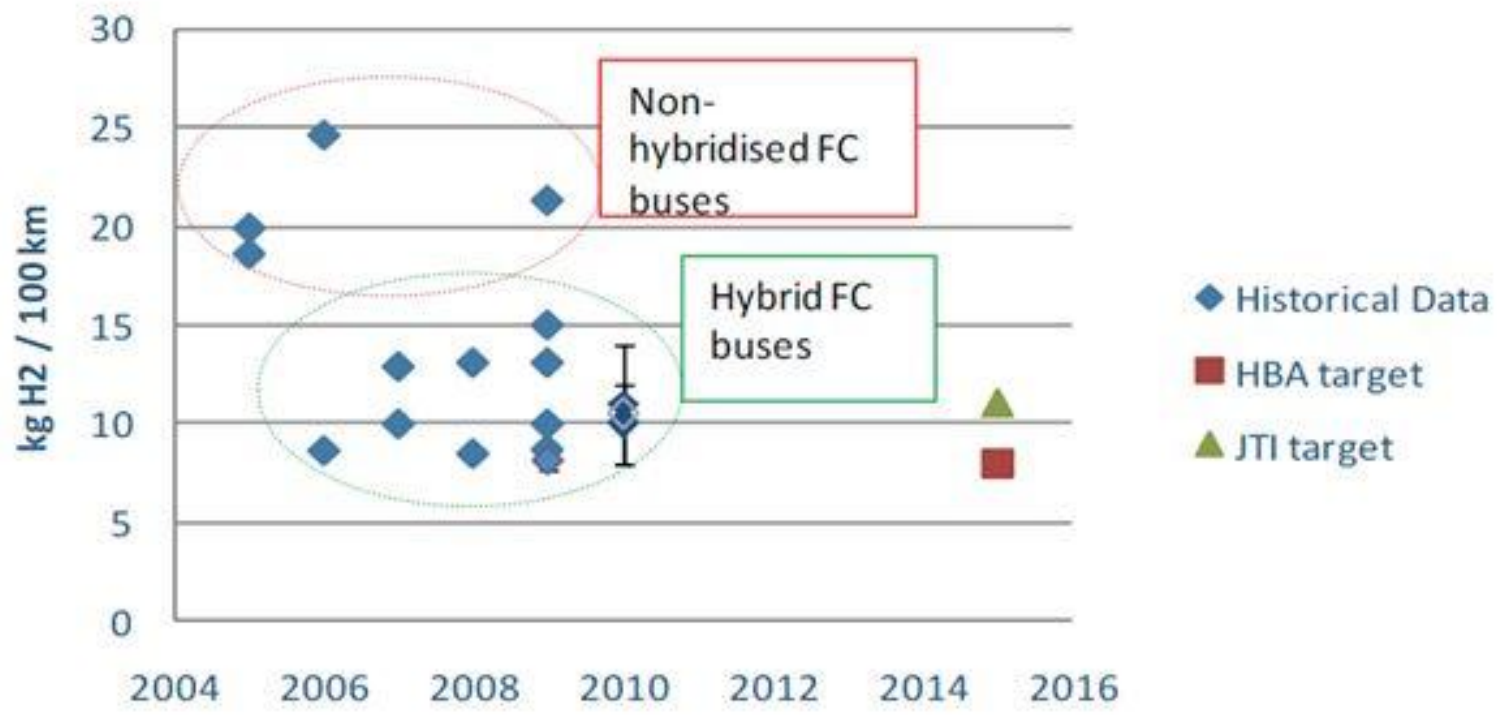

Figure 41. Current and future expected FCEB fuel economy (Source: Nexthylights) 